\title{
DESAFIOS E PERSPECTIVAS PARA INCLUSÃO DE PORTADORES DE NECESSIDADES ESPECIAIS EM EMPRESAS DE CONSTRUÇÃO CIVIL
}

\section{ARTIGO ORIGINAL}

QUADROS, Eduardo Nunes ${ }^{1}$

QUADROS, Eduardo Nunes. Desafios e perspectivas para inclusão de Portadores de Necessidades Especiais em empresas de Construção Civil. Revista Científica Multidisciplinar Núcleo do Conhecimento. Ano 05, Ed. 08, Vol. 01, pp. 171-197. Agosto de 2020. ISSN: 2448-0959, Link de acesso: https://www.nucleodoconhecimento.com.br/engenharia-civil/portadores-de$\underline{\text { necessidades }}$

\section{RESUMO}

O direito ao acesso por parte das Pessoas com Necessidades Especiais tem sido uma das pautas mais abordadas nos últimos anos, mas essa acessibilidade precisa também ser discutida no âmbito do acesso ao trabalho. Já existe uma Lei de cotas para serem seguidas pelas empresas, mas ainda não é totalmente eficaz. No âmbito das empresas de Construção Civil, tem sido um grande desafio incluir funcionários portadores de necessidades especiais, sendo esse um dos motivos que justificam a relevância deste estudo. Diante disso, objetiva-se, com esse artigo, abordar os desafios e perspectivas para a inclusão de Portadores de Necessidades Especiais. Para tanto, a partir de uma pesquisa bibliográfica, foram analisados livros, artigos e relatórios que ilustram o panorama nesse segmento no que diz respeito à inserção de funcionários portadores de necessidades especiais. Verificou-se que é possível

\footnotetext{
${ }^{1}$ Mestre em Direito e Comércio Internacional pela Universidad Europea del Atlántico. Engenheiro Civil pela Fumec-BH (MG) e Bacharéu em Direito pela Unievangélica de Anápolis (GO).
} 
contratar Portadores de Necessidades Especiais em empresas de construção civil, mas há a necessidade de subsídios técnicos para a inserção destes. É necessário seguir as matrizes de viabilidade, levando em consideração o tipo de deficiência e a função a ser designada. Tem-se como norte a seguinte pergunta-problema: de que forma os Portadores de Necessidades Especiais têm as suas demandas atendidas no contexto laboral?

Palavras-chave: Construção Civil, acessibilidade, Portadores de Necessidades Especiais.

\section{INTRODUÇÃO}

De acordo com o Censo Populacional de 2010, no Brasil há 45,6 milhões de pessoas, no país, com alguma deficiência autorreferida, ou seja, 23,9\% da população total e, nos últimos anos, tem crescido a preocupação por parte da sociedade no que diz respeito aos direitos das Pessoas com Necessidades Especiais (IBGE, 2018). Para tanto, tem sido lançadas campanhas que buscam uma maior conscientização por parte do Poder Público, buscando uma maior integração social por parte dessas pessoas. Contudo, apesar de a discriminação ter diminuído com o passar dos anos, ainda fica claro que a acessibilidade dessas pessoas possui limitações e essa acessibilidade tem, também, que estar ligada ao emprego. Um instrumento importante no que diz respeito à inclusão das Pessoas com Necessidades Especiais é a Convenção dos Direitos da Pessoa com Deficiência, visto que propicia a concretização de seus direitos fundamentais, principalmente os ligados à igualdade (ARAÚJO, 2001; SASSAKI, 2008).

Além disso, tem sido destinadas cotas para pessoas com necessidades especiais em algumas empresas. Nesse sentido, tem se mostrado importante a discussão acerca da diversidade em ambientes de trabalho e, nesse cenário, inclui-se as pessoas com necessidades especiais, que têm lutado por igualdades nas oportunidades de trabalho, educação, dentre outros (IGLESIAS et al, 2013). A inclusão de Portadores de Necessidades Especiais tem surgido no âmbito das empresas privadas. Segundo 
Campos et al (2013), há empresas que tem incluído esse grupo de pessoas, motivadas pelo valor que a diversidade pode gerar a elas, entretanto, há empresas que nem têm cumprido as obrigações legais impostas à elas pela lei de cotas. Várias são as barreiras que impedem os Portadores de Necessidades Especiais de serem inseridos em empresas de construção civil.

Os empresários têm se deparado com inúmeras dificuldades concernentes à captação e retenção dessas pessoas no ambiente de trabalho e as alegações estão ligadas à limitação física, falta de estrutura capaz de adaptar--se às suas necessidades, dentre outros. Diante disso, objetiva-se, com esse artigo, abordar os desafios e perspectivas para a inclusão de Portadores de Necessidades Especiais. Para tanto, serão analisados livros, artigos e relatórios que ilustram o panorama nesse segmento no que diz respeito à inserção de funcionários portadores de necessidades especiais a partir de uma pesquisa bibliográfica.

\section{ACESSIBILIDADE NO ÂMBITO PROFISSIONAL}

A Constituição Federal de 1988 aborda os temas ligados à pessoas que apresentem algum tipo de deficiência em várias passagens. Em seu Art. 7ํㅛ §XXXI, proíbe a distinção quanto ao estabelecimento de critérios específicos de inserção no mercado de trabalho, como a questão de níveis salariais diferenciados para o trabalhador "portador de deficiência". Por meio do Art. 37, §8, determina que a lei deve reservar um percentual específico dos cargos e empregos públicos para as pessoas que apresentam algum grau de "deficiência", estabelecendo preliminarmente os critérios de sua admissão. Dispõe, ainda, por meio do Art. 203, §2, que a Assistência Social deve habilitar e reabilitar as pessoas "portadoras de deficiência" e promover sua integração à vida comunitária (BRASIL, 1988).

Estabelece, também, a partir do Art. 227, §2, que o Estado tem o dever de elaborar programas de globalização comunitária do adolescente emissário de déficit a partir de treinamento para o trabalho e a coexistência e para que haja a facilitação da afluência aos bens e serviços coletivos, como a extinção de preconceitos e obstáculos de 
acessibilidade. Além disso, o seu Art. 244 remete a lei às disposições sobre a acessibilidade em áreas públicas, como ruas, edifícios e veículos de transporte coletivo, propiciando uma maior acessibilidade às pessoas com algum tipo de deficiência (BRASIL, 1988). Buscando contornar as barreiras trazidas pelo veto ao Art. 1ํㅗ IV, da Lei № 7.347/85 e antecipando-se à Lei № 8.078, de 11/09/90, e à Lei № 7.853/89 ratificou a atuação civil pública como solução processual para proteger os interesses coletivos ou difusos dos portadores com alguma necessidade especial.

Essa proteção se dá tanto pelo Ministério Público como pelas pessoas jurídicas de Direitos Públicos (ABREU, 2009). Considerando a Lei № 7.853/89, a partir de 1989, sob o prisma do Direito do Trabalho, foi realizada uma proposta de uma ação pública (ou coletiva) com o intuito de defender os trabalhadores portadores de necessidades especiais, tornando obrigatória e indispensável a construção de rampas que dão melhor acessibilidade para usuários de cadeira de rodas e muletas ao local de trabalho (LORENTZ, 2006). Ainda no âmbito do Direito do Trabalho, o Art. 8, II, tipificou como crime o ato de negar cargo público a pessoas que detém alguma necessidade especial, exclusivamente por terem essa condição. Essas pessoas poderão ser punidas com detenção de quatro anos, além do pagamento de multa (LORENTZ, 2006).

\section{OS DESAFIOS DA INSERÇÃO DAS PESSOAS COM NECESSIDADES ESPECIAIS NAS EMPRESAS}

A inserção de Pessoas com Necessidades Especiais no mercado de trabalho formal tem esbarrado em várias dificuldades. Um dos problemas é o preconceito, dificultando, assim, seu acesso aos serviços e sua inclusão social (Rocha; Lima, 2014). Após o advento da Lei № 8.213/1991 de reserva de cotas para pessoas com deficiência, a representação dessa população no mercado de trabalho do Brasil cresceu (BRASIL, 1991). Essa Lei estabelece a obrigatoriedade para as empresas, com 100 funcionários ou mais, do preenchimento de uma parcela do seu quadro funcional com pessoas com deficiência. Além disso, é estabelecido um percentual mínimo, proporcional ao número de empregados, aumentando de forma gradativa: de 
100 a 200 empregados - 2\% de cota, de 201 a $500-3 \%$, de 501 a $1000-4 \%$ e acima de $1.001-5 \%$.

Segundo Rocha e Lima (2014), de acordo com essa lei, qualquer pessoa poderá ser contratada pelas empresas privadas, independentemente do tipo de deficiência, desde que ela demonstre capacidade para assumir as atividades atinentes à vaga de trabalho ofertada. No entanto, a situação está longe de ser a ideal, pois ainda são visíveis as dificuldades encontradas. De acordo com Carvalho-Freitas (2008), existem, pelo menos, três dificuldades principais para a inserção e geração de trabalho para as Pessoas com Necessidades Especiais. A primeira diz respeito à percepção da deficiência por parte dos empresários. A segunda dificuldade está ligada à dificuldade de adequação das condições e práticas de trabalho por parte das empresas e a terceira está voltada à necessidade de avaliação da satisfação desses profissionais inseridos no mercado.

Foram realizadas pesquisas sobre a inserção do portador de deficiência nas empresas brasileiras e os gestores afirmaram sentir dificuldades em conseguir profissionais com deficiência qualificados, preparados socialmente e habilitados a trabalhar em atividades mais complexas (NEPOMUCENO; CARVALHO-FREITAS, 2008). Apontam, também, a dificuldade que eles possuem em relacionar--se com outros profissionais e o sentimento de inferioridade no dia a dia de trabalho. Para as mesmas autoras, mesmo quando esses trabalhadores se adaptam à empresa, tendem a apresentar, às vezes, comportamentos incompatíveis com a situação do trabalho. Esses fatores são justificativas comuns para a não--inserção desse grupo nas empresas.

Uma questão que merece discussão no que diz respeito à inserção de pessoas com deficiência nas empresas é quanto ao processo de "escolha" dos tipos de deficientes que podem ser contratados, ou seja, a avaliação se a contratação dos mesmos não causaria algum tipo de prejuízo para a empresa (MACCALI et al, 2015). Nesse aspecto, França et al (2008) destacam que os empresários têm optado por pessoas com deficiência visual, auditiva e, em alguns casos, a física. Outros tipos de deficiência 
são encaradas como dificultador no desenvolvimento do trabalho. No entanto, segundo Rocha e Lima (2014), as organizações têm alegado dificuldades de adequação do candidato ao perfil da empresa. São apontadas outras questões, como a inexistência de acessibilidade física dentro das organizações e, em alguns casos, da resistência da própria família do candidato.

O uso da justificativa da empresa não estar adequada as condições necessárias de acessibilidade estrutural, acabam colocando obstáculos para a contratação de pessoas com deficiência, principalmente as que apresentam dificuldade de locomoção, dependentes do uso de cadeira de rodas. Embora a Lei esteja em vigor desde 1991, ainda são muitos os Portadores de Necessidades Especiais que não conseguem se colocar no mercado de trabalho, revelando uma dificuldade na acessibilidade plena dessas pessoas (ROBBINS et al, 2010). Maccali et al (2015) alertam que além do direito assegurado por lei, é necessária uma reflexão sobre a efetiva inclusão das pessoas com necessidades especiais no mercado de trabalho. Trata-se, portanto, de um aspecto que depende tanto das condições estruturais e organizacionais como de preparo profissional.

Essa inclusão deve ir além da captação e absorção das PcDs, devendo ser adotadas práticas realmente efetivas de diversidade nas organizações, investindo na estrutura física e, também, na conscientização dos funcionários (SANTOS et al, 2015). De acordo com Araújo et al (2014), vários são os motivos que têm levado as empresas a adotar práticas de inclusão de pessoas com necessidades especiais e uma delas é o fato da empresa poder aproveitar as diferenças positivas dos seus profissionais, o que irá contribuir para a percepção dos consumidores de valores sociais adotados pela empresa, fortalecendo, dessa forma, seu desempenho financeiro, bem como a obtenção de maximização da produtividade e captação de novos investidores. Gil (2002), elenca outras vantagens, tais como:

a) o desempenho e a produtividade das Pessoas com Necessidades Especiais normalmente superam as expectativas dos gestores; 
b) melhora no clima organizacional da empresa;

c) maximização da imagem da empresa a longo;

d) motivação dos outros funcionários;

e) ambiente de trabalho mais humanizado

No entanto, na prática, nem todos os empresários se deram conta dos benefícios que esse tipo de contratação pode gerar para a empresa. Falta, ainda, uma maior conscientização de que todos, independente das suas dificuldades e limitações, merecem ter acesso ao mercado de trabalho, pois o que realmente interessa é a sua capacidade naquilo que se propõe a desempenhar. No segmento da construção civil, os desafios são maiores ainda, pois são inúmeros os problemas concernentes à adaptação e necessidades. O próximo item ilustra com maior detalhamento esses aspectos que compõem o objeto de nosso estudo.

\section{DESAFIOS E PERSPECTIVAS PARA A INCLUSÃO DE PORTADORES DE NECESSIDADES ESPECIAIS EM EMPRESAS DE CONSTRUÇÃO CIVIL}

São muitos os desafios no que diz respeito à inclusão de Portadores de Necessidades Especiais em empresas de Construção Civil. O primeira diz respeito à segurança necessária nesse ambiente de trabalho e a falta de adequações necessárias para que esses profissionais trabalhem de forma viável e segura. Cabe destacar que o setor da construção civil tem um nível alto de empregabilidade, entretanto, ainda não tem cumprido em sua totalidade as exigências de segurança e saúde de seus funcionários. Os canteiros de obras, além de serem locais suscetíveis a acidentes de trabalho, também priorizam pouco a qualidade de vida de seus funcionários. Embora a NR-18, a partir de suas medidas, busque assegurar a segurança e saúde dos trabalhadores, ainda é pouco aplicada em sua totalidade, principalmente nas construções de pequeno porte e com pouca fiscalização. 
Todo trabalhador está sujeito a acidentes de trabalho, entretanto, existem algumas categorias profissionais em que a incidência de acidentes é maior como, por exemplo, o ramo da construção civil. Cabe, aos empregadores, fornecerem equipamentos de forma a prevenir a incidência de acidentes (CASTRO; LAZZARI, 2009). Os acidentes de trabalho não são prejudiciais somente aos trabalhadores, mas também aos empregadores, uma vez que estes propiciam custos direitos e indiretos às empresas. A maioria dos acidentes na construção civil tomam forma devido a não utilização dos Equipamentos de Proteção Individual (EPl's) e outro aspecto importante que pouco é verificado são as áreas de vivência que ocasionam não somente acidentes de trabalho, como problemas na saúde do trabalhador e baixa qualidade de vida, propiciando, dessa forma, um aumento de absenteísmo, causando prejuízo aos empregadores.

O grupo "áreas de vivência" tem sido muito enfatizado pela fiscalização, sendo responsável por garantir as boas condições humanas para o trabalho, influenciando o bem-estar do trabalhador na diminuição nos acidentes. Entretanto, as empresas têm negligenciado muito as adequações totais nesse sentido, seguindo, na maioria das vezes, de forma parcial, as exigências da NR-18. As áreas de vivência são partes integrantes de um canteiro de obras e nela constam as instalações sanitárias, vestiário, alojamento, local de refeições, cozinha, lavanderia, área de lazer e ambulatório. De acordo com Sampaio (1998), as áreas de vivência são destinadas a suprir as necessidades básicas, dentre elas, alimentação, higiene, descanso, lazer, convivência e ambulatorial, precisando estarem fisicamente separadas das áreas laborais.

A implantação dessas áreas foi uma grande conquista por parte dos trabalhadores da construção civil, sendo obrigatórias e previstas na NR-18. Caso as empresas de construção civil contratem funcionários portadores de necessidades especiais, necessitam de uma maior adequação nas áreas de convivência para maximizar a acessibilidade dessas pessoas e isso acaba gerando um custo que os empresários não estão dispostos a arcar. Além disso, a contratação de Pessoas com necessidades Especiais pode gerar um índice grande de absenteísmo. Em 2010, foi realizado um 
estudo pela SindusCon-SP em parceria com a Associação Horizontes buscando verificar a possibilidade de inclusão dos Portadores de Necessidades Especiais, traçou detalhadamente o perfil de cada função e cada tipo de deficiência.

O quadro 1 ilustra a possibilidade de inclusão dos Portadores de Necessidades Especiais, dividindo por função e tipo de deficiência.

Quadro 1 - Análise da viabilidade de Inclusão de profissionais nas Principais Funções/Postos de Trabalho por Tipo de Deficiência

\begin{tabular}{|c|c|c|c|c|c|c|c|c|}
\hline Função & $\begin{array}{l}\text { Deficiência } \\
\text { Física } \\
\text { Nanismo }\end{array}$ & $\begin{array}{l}\text { Deficiência } \\
\text { Física } \\
\text { Membros } \\
\text { Inferiores }\end{array}$ & $\begin{array}{l}\text { Deficiência } \\
\text { Física } \\
\text { Membros } \\
\text { Superiores }\end{array}$ & $\begin{array}{l}\text { Deficiência } \\
\text { Física } \\
\text { Ostomizado }\end{array}$ & $\begin{array}{l}\text { Deficiência } \\
\text { Auditiva }\end{array}$ & $\begin{array}{c}\text { Deficiência } \\
\text { Visual }\end{array}$ & $\begin{array}{l}\text { Deficiência } \\
\text { Intelectual } \\
\text { Moderada }\end{array}$ & $\begin{array}{c}\text { Deficiência } \\
\text { intelectual } \\
\text { severa e } \\
\text { profunda }\end{array}$ \\
\hline $\begin{array}{c}\text { Ajudante } \\
\text { Geral }\end{array}$ & Recomendado & $\begin{array}{l}\text { Recomendado } \\
\text { parcialmente }\end{array}$ & $\begin{array}{c}\text { Não } \\
\text { recomendado }\end{array}$ & $\begin{array}{c}\text { Não } \\
\text { recomendado }\end{array}$ & Recomendado & $\begin{array}{c}\text { Não } \\
\text { recomendado }\end{array}$ & Recomendado & $\begin{array}{c}\text { Não } \\
\text { recomendado }\end{array}$ \\
\hline Armador & Recomendado & $\begin{array}{l}\text { Recomendado } \\
\text { parcialmente }\end{array}$ & $\begin{array}{c}\text { Não } \\
\text { recomendado }\end{array}$ & $\begin{array}{c}\text { Não } \\
\text { recomendado }\end{array}$ & Recomendado & $\begin{array}{c}\text { Não } \\
\text { recomendado }\end{array}$ & Recomendado & $\begin{array}{c}\text { Não } \\
\text { recomendado }\end{array}$ \\
\hline Azulejista & Recomendado & $\begin{array}{l}\text { Recomendado } \\
\text { parcialmente }\end{array}$ & $\begin{array}{c}\text { Não } \\
\text { recomendado }\end{array}$ & $\begin{array}{c}\text { Não } \\
\text { recomendado }\end{array}$ & Recomendado & $\begin{array}{c}\text { Não } \\
\text { recomendado }\end{array}$ & Recomendado & $\begin{array}{c}\text { Não } \\
\text { recomendado }\end{array}$ \\
\hline Cabista & Recomendado & $\begin{array}{l}\text { Recomendado } \\
\text { parcialmente }\end{array}$ & $\begin{array}{c}\text { Não } \\
\text { recomendado }\end{array}$ & $\begin{array}{c}\text { Não } \\
\text { recomendado }\end{array}$ & Recomendado & $\begin{array}{c}\text { Não } \\
\text { recomendado }\end{array}$ & $\begin{array}{l}\text { Recomendado } \\
\text { parcialmente }\end{array}$ & $\begin{array}{c}\text { Não } \\
\text { recomendado }\end{array}$ \\
\hline Carpinteiro & Recomendado & $\begin{array}{l}\text { Recomendado } \\
\text { parcialmente }\end{array}$ & $\begin{array}{c}\text { Não } \\
\text { recomendado }\end{array}$ & $\begin{array}{c}\text { Não } \\
\text { recomendado }\end{array}$ & Recomendado & $\begin{array}{c}\text { Não } \\
\text { recomendado }\end{array}$ & $\begin{array}{c}\text { Recomendado } \\
\text { parcialmente }\end{array}$ & $\begin{array}{c}\text { Não } \\
\text { recomendado }\end{array}$ \\
\hline Eletricista & Recomendado & $\begin{array}{l}\text { Recomendado } \\
\text { parcialmente }\end{array}$ & $\begin{array}{c}\text { Não } \\
\text { recomendado }\end{array}$ & $\begin{array}{l}\text { Recomendado } \\
\text { parcialmente }\end{array}$ & Recomendado & $\begin{array}{c}\text { Não } \\
\text { recomendado }\end{array}$ & $\begin{array}{l}\text { Recomendado } \\
\text { parcialmente }\end{array}$ & $\begin{array}{c}\text { Não } \\
\text { recomendado }\end{array}$ \\
\hline Encanador & Recomendado & $\begin{array}{l}\text { Recomendado } \\
\text { parcialmente }\end{array}$ & $\begin{array}{c}\text { Não } \\
\text { recomendado }\end{array}$ & $\begin{array}{c}\text { Não } \\
\text { recomendado }\end{array}$ & Recomendado & $\begin{array}{c}\text { Não } \\
\text { recomendado }\end{array}$ & $\begin{array}{c}\text { Recomendado } \\
\text { parcialmente }\end{array}$ & $\begin{array}{c}\text { Não } \\
\text { recomendado }\end{array}$ \\
\hline Gesseiro & Recomendado & $\begin{array}{l}\text { Recomendado } \\
\text { parcialmente }\end{array}$ & $\begin{array}{c}\text { Não } \\
\text { recomendado }\end{array}$ & $\begin{array}{c}\text { Não } \\
\text { recomendado }\end{array}$ & Recomendado & $\begin{array}{c}\text { Não } \\
\text { recomendado }\end{array}$ & $\begin{array}{c}\text { Recomendado } \\
\text { parcialmente }\end{array}$ & $\begin{array}{c}\text { Não } \\
\text { recomendado }\end{array}$ \\
\hline $\begin{array}{c}\text { Mestre de } \\
\text { obras }\end{array}$ & Recomendado & $\begin{array}{l}\text { Recomendado } \\
\text { parcialmente }\end{array}$ & $\begin{array}{c}\text { Não } \\
\text { recomendado }\end{array}$ & $\begin{array}{c}\text { Não } \\
\text { recomendado }\end{array}$ & $\begin{array}{c}\text { Não } \\
\text { recomendado }\end{array}$ & $\begin{array}{c}\text { Não } \\
\text { recomendado }\end{array}$ & Não recomendado & $\begin{array}{c}\text { Não } \\
\text { recomendado }\end{array}$ \\
\hline $\begin{array}{l}\text { Operador } \\
\text { escavadeira }\end{array}$ & $\begin{array}{l}\text { Recomendado } \\
\text { parcialmente }\end{array}$ & $\begin{array}{l}\text { Recomendado } \\
\text { parcialmente }\end{array}$ & $\begin{array}{c}\text { Não } \\
\text { recomendado }\end{array}$ & $\begin{array}{l}\text { Recomendado } \\
\text { parcialmente }\end{array}$ & $\begin{array}{c}\text { Não } \\
\text { recomendado }\end{array}$ & $\begin{array}{c}\text { Não } \\
\text { recomendado }\end{array}$ & Não recomendado & $\begin{array}{c}\text { Não } \\
\text { recomendado }\end{array}$ \\
\hline $\begin{array}{l}\text { Operador } \\
\text { Grua }\end{array}$ & $\begin{array}{l}\text { Recomendado } \\
\text { parcialmente }\end{array}$ & $\begin{array}{l}\text { Recomendado } \\
\text { parcialmente }\end{array}$ & $\begin{array}{c}\text { Não } \\
\text { recomendado }\end{array}$ & $\begin{array}{l}\text { Recomendado } \\
\text { parcialmente }\end{array}$ & $\begin{array}{c}\text { Não } \\
\text { recomendado }\end{array}$ & $\begin{array}{c}\text { Não } \\
\text { recomendado }\end{array}$ & Não recomendado & $\begin{array}{c}\text { Não } \\
\text { recomendado }\end{array}$ \\
\hline $\begin{array}{l}\text { Operador } \\
\text { Guincho }\end{array}$ & $\begin{array}{l}\text { Recomendado } \\
\text { parcialmente }\end{array}$ & $\begin{array}{l}\text { Recomendado } \\
\text { parcialmente }\end{array}$ & $\begin{array}{c}\text { Não } \\
\text { recomendado }\end{array}$ & $\begin{array}{l}\text { Recomendado } \\
\text { parcialmente }\end{array}$ & $\begin{array}{c}\text { Não } \\
\text { recomendado }\end{array}$ & $\begin{array}{c}\text { Não } \\
\text { recomendado }\end{array}$ & Não recomendado & $\begin{array}{c}\text { Não } \\
\text { recomendado }\end{array}$ \\
\hline $\begin{array}{l}\text { Operador } \\
\text { Guindaste }\end{array}$ & $\begin{array}{l}\text { Recomendado } \\
\text { parcialmente }\end{array}$ & $\begin{array}{l}\text { Recomendado } \\
\text { parcialmente }\end{array}$ & $\begin{array}{c}\text { Não } \\
\text { recomendado }\end{array}$ & $\begin{array}{l}\text { Recomendado } \\
\text { parcialmente }\end{array}$ & $\begin{array}{c}\text { Não } \\
\text { recomendado }\end{array}$ & $\begin{array}{c}\text { Não } \\
\text { recomendado }\end{array}$ & Não recomendado & $\begin{array}{c}\text { Não } \\
\text { recomendado }\end{array}$ \\
\hline Pedreiro & Recomendado & $\begin{array}{l}\text { Recomendado } \\
\text { parcialmente }\end{array}$ & $\begin{array}{c}\text { Não } \\
\text { recomendado }\end{array}$ & $\begin{array}{c}\text { Não } \\
\text { recomendado }\end{array}$ & Recomendado & $\begin{array}{c}\text { Não } \\
\text { recomendado }\end{array}$ & $\begin{array}{l}\text { Recomendado } \\
\text { parcialmente }\end{array}$ & $\begin{array}{c}\text { Não } \\
\text { recomendado }\end{array}$ \\
\hline $\begin{array}{l}\text { Pedreiro } \\
\text { Fachada }\end{array}$ & Recomendado & $\begin{array}{l}\text { Recomendado } \\
\text { parcialmente }\end{array}$ & $\begin{array}{c}\text { Não } \\
\text { recomendado }\end{array}$ & $\begin{array}{c}\text { Não } \\
\text { recomendado }\end{array}$ & Recomendado & $\begin{array}{c}\text { Não } \\
\text { recomendado }\end{array}$ & $\begin{array}{l}\text { Recomendado } \\
\text { parcialmente }\end{array}$ & $\begin{array}{c}\text { Não } \\
\text { recomendado }\end{array}$ \\
\hline Pintor & Recomendado & $\begin{array}{l}\text { Recomendado } \\
\text { parcialmente }\end{array}$ & $\begin{array}{c}\text { Não } \\
\text { recomendado }\end{array}$ & $\begin{array}{c}\text { Não } \\
\text { recomendado }\end{array}$ & Recomendado & $\begin{array}{c}\text { Não } \\
\text { recomendado }\end{array}$ & $\begin{array}{l}\text { Recomendado } \\
\text { parcialmente }\end{array}$ & $\begin{array}{c}\text { Não } \\
\text { recomendado }\end{array}$ \\
\hline Poceiro & Recomendado & $\begin{array}{l}\text { Recomendado } \\
\text { parcialmente }\end{array}$ & $\begin{array}{c}\text { Não } \\
\text { recomendado }\end{array}$ & $\begin{array}{c}\text { Não } \\
\text { recomendado }\end{array}$ & Recomendado & $\begin{array}{c}\text { Não } \\
\text { recomendado }\end{array}$ & Recomendado & $\begin{array}{c}\text { Não } \\
\text { recomendado }\end{array}$ \\
\hline Serralheiro & Recomendado & $\begin{array}{l}\text { Recomendado } \\
\text { parcialmente }\end{array}$ & $\begin{array}{c}\text { Não } \\
\text { recomendado }\end{array}$ & $\begin{array}{c}\text { Não } \\
\text { recomendado }\end{array}$ & Recomendado & $\begin{array}{c}\text { Não } \\
\text { recomendado }\end{array}$ & Restrição parcial & $\begin{array}{c}\text { Não } \\
\text { recomendado }\end{array}$ \\
\hline
\end{tabular}

Fonte: Relatório do Estudo Sobre Inclusão de PCDs: Setor da Construção Civil SindusCon-SP/Associação Horizontes - Janeiro/2010

Outro estudo foi realizado pela Sinduscon/SP (2015) buscando avaliar a viabilidade de inserção de forma segura de Portadores de Necessidades Especiais em canteiros de obra. Foram realizadas entrevistas com Engenheiros, Mestres de Obra e Encarregados para avaliar se existe segurança na inserção desses profissionais e isso foi realizado por meio de simulações, levando em consideração o tipo de deficiência e os postos de trabalho, os cargos e funções nesse tipo de trabalho. Ao entrevistar os

Disponível em: https://www.nucleodoconhecimento.com.br/engenharia-civil/portadores-de- 
Engenheiros e os Mestres de obras e Encarregados, o Sinduscon/SP (2015) obteve a opinião dos mesmos acerca da distribuição das principais funções da construção civil para os profissionais portadores de necessidades especiais (quadro 2).

Quadro 2 - Distribuição das Principais Funções da Construção Civil Segundo Pesquisa de Opinião para Análise de Viabilidade de Inserção por Tipo de Deficiência - Entrevista com Engenheiros e Mestres de Obra/Encarregados

\begin{tabular}{|c|c|c|c|c|c|c|c|c|}
\hline Função & $\begin{array}{l}\text { Deficiência } \\
\text { Física } \\
\text { Nanismo }\end{array}$ & $\begin{array}{l}\text { Deficiência } \\
\text { Física } \\
\text { Membros } \\
\text { Inferiores }\end{array}$ & $\begin{array}{c}\text { Deficiência } \\
\text { Física } \\
\text { Membros } \\
\text { Superiores }\end{array}$ & $\begin{array}{l}\text { Deficiência } \\
\text { Física } \\
\text { Ostomizado }\end{array}$ & $\begin{array}{l}\text { Deficiência } \\
\text { Auditiva }\end{array}$ & $\begin{array}{l}\text { Deficiência } \\
\text { Visual }\end{array}$ & $\begin{array}{l}\text { Deficiência } \\
\text { Intelectual } \\
\text { Moderada }\end{array}$ & $\begin{array}{c}\text { Deficiência } \\
\text { intelectual } \\
\text { severa e } \\
\text { profunda }\end{array}$ \\
\hline $\begin{array}{l}\text { Ajudante } \\
\text { Geral }\end{array}$ & $\begin{array}{c}\text { Não } \\
\text { Recomendado }\end{array}$ & $\begin{array}{l}\text { Recomendado } \\
\text { parcialmente }\end{array}$ & $\begin{array}{c}\text { Não } \\
\text { recomendado }\end{array}$ & $\begin{array}{c}\text { Não } \\
\text { recomendado }\end{array}$ & $\begin{array}{c}\text { Não } \\
\text { recomendado }\end{array}$ & $\begin{array}{c}\text { Não } \\
\text { recomendado }\end{array}$ & $\begin{array}{l}\text { Recomendado } \\
\text { parcialmente }\end{array}$ & $\begin{array}{c}\text { Não } \\
\text { recomendado }\end{array}$ \\
\hline Armador & $\begin{array}{l}\text { Recomendado } \\
\text { parcialmente }\end{array}$ & $\begin{array}{l}\text { Recomendado } \\
\text { parcialmente }\end{array}$ & $\begin{array}{c}\text { Não } \\
\text { recomendado }\end{array}$ & $\begin{array}{c}\text { Não } \\
\text { recomendado }\end{array}$ & $\begin{array}{l}\text { Recomendado } \\
\text { parcialmente }\end{array}$ & $\begin{array}{c}\text { Não } \\
\text { recomendado }\end{array}$ & $\begin{array}{l}\text { Recomendado } \\
\text { parcialmente }\end{array}$ & $\begin{array}{c}\text { Não } \\
\text { recomendado }\end{array}$ \\
\hline Azulejista & $\begin{array}{l}\text { Recomendado } \\
\text { parcialmente }\end{array}$ & Recomendado & $\begin{array}{c}\text { Não } \\
\text { recomendado }\end{array}$ & $\begin{array}{c}\text { Não } \\
\text { recomendado }\end{array}$ & $\begin{array}{l}\text { Recomendado } \\
\text { parcialmente }\end{array}$ & $\begin{array}{c}\text { Não } \\
\text { recomendado }\end{array}$ & $\begin{array}{c}\text { Não } \\
\text { Recomendado }\end{array}$ & $\begin{array}{c}\text { Não } \\
\text { recomendado }\end{array}$ \\
\hline Cabista & Não analisado & Não analisado & $\begin{array}{c}\text { Não } \\
\text { recomendado }\end{array}$ & $\begin{array}{c}\text { Não } \\
\text { recomendado }\end{array}$ & Não analisado & $\begin{array}{c}\text { Não } \\
\text { recomendado }\end{array}$ & Não analisado & $\begin{array}{c}\text { Não } \\
\text { recomendado }\end{array}$ \\
\hline Carpinteiro & $\begin{array}{l}\text { Recomendado } \\
\text { parcialmente }\end{array}$ & $\begin{array}{l}\text { Recomendado } \\
\text { parcialmente }\end{array}$ & $\begin{array}{c}\text { Não } \\
\text { recomendado }\end{array}$ & $\begin{array}{c}\text { Não } \\
\text { recomendado }\end{array}$ & $\begin{array}{l}\text { Recomendado } \\
\text { parcialmente }\end{array}$ & $\begin{array}{c}\text { Não } \\
\text { recomendado }\end{array}$ & $\begin{array}{c}\text { Não } \\
\text { Recomendado }\end{array}$ & $\begin{array}{c}\text { Não } \\
\text { recomendado }\end{array}$ \\
\hline Eletricista & $\begin{array}{l}\text { Recomendado } \\
\text { parcialmente }\end{array}$ & Recomendado & $\begin{array}{c}\text { Não } \\
\text { recomendado }\end{array}$ & $\begin{array}{l}\text { Recomendado } \\
\text { parcialmente }\end{array}$ & $\begin{array}{c}\text { Recomendado } \\
\text { parcialmente }\end{array}$ & $\begin{array}{c}\text { Não } \\
\text { recomendado }\end{array}$ & $\begin{array}{c}\text { Não } \\
\text { Recomendado }\end{array}$ & $\begin{array}{c}\text { Não } \\
\text { recomendado }\end{array}$ \\
\hline Encanador & $\begin{array}{l}\text { Recomendado } \\
\text { parcialmente }\end{array}$ & $\begin{array}{l}\text { Recomendado } \\
\text { parcialmente }\end{array}$ & $\begin{array}{c}\text { Não } \\
\text { recomendado }\end{array}$ & $\begin{array}{c}\text { Não } \\
\text { recomendado }\end{array}$ & $\begin{array}{l}\text { Recomendado } \\
\text { parcialmente }\end{array}$ & $\begin{array}{c}\text { Não } \\
\text { recomendado }\end{array}$ & $\begin{array}{c}\text { Não } \\
\text { Recomendado }\end{array}$ & $\begin{array}{c}\text { Não } \\
\text { recomendado }\end{array}$ \\
\hline Gesseiro & $\begin{array}{l}\text { Recomendado } \\
\text { parcialmente }\end{array}$ & $\begin{array}{l}\text { Recomendado } \\
\text { parcialmente }\end{array}$ & $\begin{array}{c}\text { Não } \\
\text { recomendado }\end{array}$ & $\begin{array}{c}\text { Não } \\
\text { recomendado }\end{array}$ & $\begin{array}{c}\text { Recomendado } \\
\text { parcialmente }\end{array}$ & $\begin{array}{c}\text { Não } \\
\text { recomendado }\end{array}$ & $\begin{array}{c}\text { Não } \\
\text { Recomendado }\end{array}$ & $\begin{array}{c}\text { Não } \\
\text { recomendado }\end{array}$ \\
\hline $\begin{array}{c}\text { Mestre de } \\
\text { obras }\end{array}$ & $\begin{array}{c}\text { Não } \\
\text { Recomendado }\end{array}$ & $\begin{array}{l}\text { Recomendado } \\
\text { parcialmente }\end{array}$ & $\begin{array}{c}\text { Não } \\
\text { recomendado }\end{array}$ & $\begin{array}{c}\text { Não } \\
\text { recomendado }\end{array}$ & $\begin{array}{l}\text { Recomendado } \\
\text { parcialmente }\end{array}$ & $\begin{array}{c}\text { Não } \\
\text { recomendado }\end{array}$ & $\begin{array}{c}\text { Não } \\
\text { Recomendado }\end{array}$ & $\begin{array}{c}\text { Não } \\
\text { recomendado }\end{array}$ \\
\hline $\begin{array}{l}\text { Operador } \\
\text { escavadeira }\end{array}$ & $\begin{array}{c}\text { Não } \\
\text { Recomendado }\end{array}$ & $\begin{array}{l}\text { Recomendado } \\
\text { parcialmente }\end{array}$ & $\begin{array}{c}\text { Não } \\
\text { recomendado }\end{array}$ & $\begin{array}{c}\text { Recomendado } \\
\text { parcialmente }\end{array}$ & $\begin{array}{l}\text { Recomendado } \\
\text { parcialmente }\end{array}$ & $\begin{array}{c}\text { Não } \\
\text { recomendado }\end{array}$ & $\begin{array}{c}\text { Não } \\
\text { Recomendado }\end{array}$ & $\begin{array}{c}\text { Não } \\
\text { recomendado }\end{array}$ \\
\hline $\begin{array}{c}\text { Operador } \\
\text { Grua }\end{array}$ & $\begin{array}{l}\text { Recomendado } \\
\text { parcialmente }\end{array}$ & $\begin{array}{l}\text { Recomendado } \\
\text { parcialmente }\end{array}$ & $\begin{array}{c}\text { Não } \\
\text { recomendado }\end{array}$ & $\begin{array}{l}\text { Recomendado } \\
\text { parcialmente }\end{array}$ & $\begin{array}{c}\text { Não } \\
\text { recomendado }\end{array}$ & $\begin{array}{c}\text { Não } \\
\text { recomendado }\end{array}$ & $\begin{array}{c}\text { Não } \\
\text { Recomendado }\end{array}$ & $\begin{array}{c}\text { Não } \\
\text { recomendado }\end{array}$ \\
\hline $\begin{array}{l}\text { Operador } \\
\text { Guincho }\end{array}$ & $\begin{array}{l}\text { Recomendado } \\
\text { parcialmente }\end{array}$ & $\begin{array}{l}\text { Recomendado } \\
\text { parcialmente }\end{array}$ & $\begin{array}{c}\text { Não } \\
\text { recomendado }\end{array}$ & $\begin{array}{l}\text { Recomendado } \\
\text { parcialmente }\end{array}$ & $\begin{array}{c}\text { Não } \\
\text { recomendado }\end{array}$ & $\begin{array}{c}\text { Não } \\
\text { recomendado }\end{array}$ & $\begin{array}{c}\text { Não } \\
\text { Recomendado }\end{array}$ & $\begin{array}{c}\text { Não } \\
\text { recomendado }\end{array}$ \\
\hline $\begin{array}{l}\text { Operador } \\
\text { Guindaste }\end{array}$ & $\begin{array}{c}\text { Não } \\
\text { Recomendado }\end{array}$ & $\begin{array}{l}\text { Recomendado } \\
\text { parcialmente }\end{array}$ & $\begin{array}{c}\text { Não } \\
\text { recomendado }\end{array}$ & $\begin{array}{l}\text { Recomendado } \\
\text { parcialmente }\end{array}$ & $\begin{array}{c}\text { Não } \\
\text { recomendado }\end{array}$ & $\begin{array}{c}\text { Não } \\
\text { recomendado }\end{array}$ & $\begin{array}{c}\text { Não } \\
\text { Recomendado }\end{array}$ & $\begin{array}{c}\text { Não } \\
\text { recomendado }\end{array}$ \\
\hline Pedreiro & $\begin{array}{l}\text { Recomendado } \\
\text { parcialmente }\end{array}$ & $\begin{array}{l}\text { Recomendado } \\
\text { parcialmente }\end{array}$ & $\begin{array}{c}\text { Não } \\
\text { recomendado }\end{array}$ & $\begin{array}{c}\text { Não } \\
\text { recomendado }\end{array}$ & Recomendado & $\begin{array}{c}\text { Não } \\
\text { recomendado }\end{array}$ & $\begin{array}{c}\text { Não } \\
\text { Recomendado }\end{array}$ & $\begin{array}{c}\text { Não } \\
\text { recomendado }\end{array}$ \\
\hline $\begin{array}{l}\text { Pedreiro } \\
\text { Fachada }\end{array}$ & $\begin{array}{c}\text { Não } \\
\text { Recomendado }\end{array}$ & $\begin{array}{l}\text { Recomendado } \\
\text { parcialmente }\end{array}$ & $\begin{array}{c}\text { Não } \\
\text { recomendado }\end{array}$ & $\begin{array}{c}\text { Não } \\
\text { recomendado }\end{array}$ & $\begin{array}{c}\text { Não } \\
\text { Recomendado }\end{array}$ & $\begin{array}{c}\text { Não } \\
\text { recomendado }\end{array}$ & $\begin{array}{c}\text { Não } \\
\text { Recomendado }\end{array}$ & $\begin{array}{c}\text { Não } \\
\text { recomendado }\end{array}$ \\
\hline Pintor & $\begin{array}{l}\text { Recomendado } \\
\text { parcialmente }\end{array}$ & Recomendado & $\begin{array}{c}\text { Não } \\
\text { recomendado }\end{array}$ & $\begin{array}{c}\text { Não } \\
\text { recomendado }\end{array}$ & $\begin{array}{c}\begin{array}{c}\text { Recomendado } \\
\text { parcialmente }\end{array} \\
\end{array}$ & $\begin{array}{c}\text { Não } \\
\text { recomendado }\end{array}$ & $\begin{array}{c}\text { Não } \\
\text { Recomendado }\end{array}$ & $\begin{array}{c}\text { Não } \\
\text { recomendado }\end{array}$ \\
\hline Poceiro & $\begin{array}{c}\text { Não } \\
\text { Recomendado }\end{array}$ & $\begin{array}{l}\text { Recomendado } \\
\text { parcialmente }\end{array}$ & $\begin{array}{c}\text { Não } \\
\text { recomendado }\end{array}$ & $\begin{array}{c}\text { Não } \\
\text { recomendado }\end{array}$ & $\begin{array}{c}\text { Não } \\
\text { Recomendado }\end{array}$ & $\begin{array}{c}\text { Não } \\
\text { recomendado }\end{array}$ & $\begin{array}{c}\text { Não } \\
\text { Recomendado }\end{array}$ & $\begin{array}{c}\text { Não } \\
\text { recomendado }\end{array}$ \\
\hline Serralheiro & $\begin{array}{c}\text { Não } \\
\text { Recomendado } \\
\end{array}$ & $\begin{array}{c}\text { Recomendado } \\
\text { parcialmente }\end{array}$ & $\begin{array}{c}\text { Não } \\
\text { recomendado }\end{array}$ & $\begin{array}{c}\text { Não } \\
\text { recomendado }\end{array}$ & $\begin{array}{c}\begin{array}{c}\text { Recomendado } \\
\text { parcialmente }\end{array} \\
\end{array}$ & $\begin{array}{c}\text { Não } \\
\text { recomendado }\end{array}$ & $\begin{array}{c}\text { Não } \\
\text { Recomendado }\end{array}$ & $\begin{array}{c}\text { Não } \\
\text { recomendado }\end{array}$ \\
\hline
\end{tabular}

Fonte: Sinduscon/SP (2015)

O quadro 3 ilustra a distribuição das principais funções da Construção Civil segundo Análise Técnica de Viabilidade de Inserção por Tipo de Deficiência - Saúde e Segurança no Trabalho - SECONCI-SP.

Disponível em: https://www.nucleodoconhecimento.com.br/engenharia-civil/portadores-denecessidades 
Quadro 3 - Distribuição das Principais Funções da Construção Civil Segundo Análise Técnica de Viabilidade de Inserção por Tipo de Deficiência - Saúde e Segurança no Trabalho - SECONCI-SP

\begin{tabular}{|c|c|c|c|c|c|c|c|c|}
\hline Função & $\begin{array}{l}\text { Deficiência } \\
\text { Física } \\
\text { Nanismo }\end{array}$ & $\begin{array}{l}\text { Deficiência } \\
\text { Física } \\
\text { Membros } \\
\text { Inferiores }\end{array}$ & $\begin{array}{l}\text { Deficiência } \\
\text { Física } \\
\text { Membros } \\
\text { Superiores }\end{array}$ & $\begin{array}{l}\text { Deficiência } \\
\text { Física } \\
\text { Ostomizado }\end{array}$ & $\begin{array}{l}\text { Deficiência } \\
\text { Auditiva }\end{array}$ & $\begin{array}{c}\text { Deficiência } \\
\text { Visual }\end{array}$ & $\begin{array}{l}\text { Deficiência } \\
\text { Intelectual } \\
\text { Moderada }\end{array}$ & $\begin{array}{c}\text { Deficiência } \\
\text { intelectual } \\
\text { severa e } \\
\text { profunda }\end{array}$ \\
\hline $\begin{array}{l}\text { Ajudante } \\
\text { Geral }\end{array}$ & $\begin{array}{l}\text { Recomendado } \\
\text { parcialmente }\end{array}$ & $\begin{array}{l}\text { Recomendado } \\
\text { parcialmente }\end{array}$ & $\begin{array}{c}\text { Não } \\
\text { recomendado }\end{array}$ & $\begin{array}{c}\text { Não } \\
\text { recomendado }\end{array}$ & Recomendado & $\begin{array}{c}\text { Não } \\
\text { recomendado }\end{array}$ & $\begin{array}{l}\text { Recomendado } \\
\text { parcialmente }\end{array}$ & $\begin{array}{c}\text { Não } \\
\text { recomendado }\end{array}$ \\
\hline Armador & $\begin{array}{l}\text { Recomendado } \\
\text { parcialmente }\end{array}$ & $\begin{array}{l}\text { Recomendado } \\
\text { parcialmente }\end{array}$ & $\begin{array}{l}\text { Não } \\
\text { recomendado }\end{array}$ & $\begin{array}{c}\text { Não } \\
\text { recomendado }\end{array}$ & Recomendado & $\begin{array}{c}\text { Não } \\
\text { recomendado }\end{array}$ & $\begin{array}{l}\text { Recomendado } \\
\text { parcialmente }\end{array}$ & $\begin{array}{c}\text { Não } \\
\text { recomendado }\end{array}$ \\
\hline Azulejista & $\begin{array}{l}\text { Recomendado } \\
\text { parcialmente }\end{array}$ & Recomendado & $\begin{array}{c}\text { Não } \\
\text { recomendado }\end{array}$ & $\begin{array}{c}\text { Não } \\
\text { recomendado }\end{array}$ & $\begin{array}{c}\text { Recomendado } \\
\text { parcialmente }\end{array}$ & $\begin{array}{c}\text { Não } \\
\text { recomendado }\end{array}$ & $\begin{array}{c}\text { Não } \\
\text { Recomendado }\end{array}$ & $\begin{array}{c}\text { Não } \\
\text { recomendado }\end{array}$ \\
\hline Cabista & Não analisado & Não analisado & $\begin{array}{c}\text { Não } \\
\text { recomendado }\end{array}$ & $\begin{array}{c}\text { Não } \\
\text { recomendado }\end{array}$ & Não analisado & $\begin{array}{c}\text { Não } \\
\text { recomendado }\end{array}$ & Não analisado & $\begin{array}{c}\text { Não } \\
\text { recomendado }\end{array}$ \\
\hline Carpinteiro & $\begin{array}{l}\text { Recomendado } \\
\text { parcialmente }\end{array}$ & $\begin{array}{l}\text { Recomendado } \\
\text { parcialmente }\end{array}$ & $\begin{array}{c}\text { Não } \\
\text { recomendado }\end{array}$ & $\begin{array}{c}\text { Não } \\
\text { recomendado }\end{array}$ & $\begin{array}{l}\text { Recomendado } \\
\text { parcialmente }\end{array}$ & $\begin{array}{c}\text { Não } \\
\text { recomendado }\end{array}$ & $\begin{array}{l}\text { Recomendado } \\
\text { parcialmente }\end{array}$ & $\begin{array}{c}\text { Não } \\
\text { recomendado }\end{array}$ \\
\hline Eletricista & $\begin{array}{l}\text { Recomendado } \\
\text { parcialmente }\end{array}$ & $\begin{array}{l}\text { Recomendado } \\
\text { parcialmente }\end{array}$ & $\begin{array}{c}\text { Não } \\
\text { recomendado }\end{array}$ & $\begin{array}{c}\text { Não } \\
\text { recomendado }\end{array}$ & $\begin{array}{l}\text { Recomendado } \\
\text { parcialmente }\end{array}$ & $\begin{array}{c}\text { Não } \\
\text { recomendado }\end{array}$ & $\begin{array}{c}\text { Não } \\
\text { Recomendado }\end{array}$ & $\begin{array}{c}\text { Não } \\
\text { recomendado }\end{array}$ \\
\hline Encanador & $\begin{array}{l}\text { Recomendado } \\
\text { parcialmente }\end{array}$ & $\begin{array}{l}\text { Recomendado } \\
\text { parcialmente }\end{array}$ & $\begin{array}{c}\text { Não } \\
\text { recomendado }\end{array}$ & $\begin{array}{c}\text { Não } \\
\text { recomendado }\end{array}$ & $\begin{array}{l}\text { Recomendado } \\
\text { parcialmente }\end{array}$ & $\begin{array}{c}\text { Não } \\
\text { recomendado }\end{array}$ & $\begin{array}{c}\text { Não } \\
\text { Recomendado }\end{array}$ & $\begin{array}{c}\text { Não } \\
\text { recomendado }\end{array}$ \\
\hline Gesseiro & $\begin{array}{l}\text { Recomendado } \\
\text { parcialmente }\end{array}$ & $\begin{array}{l}\text { Recomendado } \\
\text { parcialmente }\end{array}$ & $\begin{array}{l}\text { Não } \\
\text { recomendado }\end{array}$ & $\begin{array}{l}\text { Não } \\
\text { recomendado }\end{array}$ & Recomendado & $\begin{array}{l}\text { Não } \\
\text { recomendado }\end{array}$ & $\begin{array}{c}\text { Não } \\
\text { Recomendado }\end{array}$ & $\begin{array}{l}\text { Não } \\
\text { recomendado }\end{array}$ \\
\hline $\begin{array}{l}\text { Mestre de } \\
\text { obras }\end{array}$ & $\begin{array}{l}\text { Recomendado } \\
\text { parcialmente }\end{array}$ & $\begin{array}{l}\text { Recomendado } \\
\text { parcialmente }\end{array}$ & $\begin{array}{c}\text { Não } \\
\text { recomendado }\end{array}$ & $\begin{array}{c}\text { Não } \\
\text { recomendado }\end{array}$ & $\begin{array}{c}\text { Recomendado } \\
\text { parcialmente }\end{array}$ & $\begin{array}{c}\text { Não } \\
\text { recomendado }\end{array}$ & $\begin{array}{c}\text { Não } \\
\text { Recomendado }\end{array}$ & $\begin{array}{c}\text { Não } \\
\text { recomendado }\end{array}$ \\
\hline $\begin{array}{l}\text { Operador } \\
\text { escavadeira }\end{array}$ & $\begin{array}{c}\text { Não } \\
\text { Recomendado }\end{array}$ & $\begin{array}{l}\text { Recomendado } \\
\text { parcialmente }\end{array}$ & $\begin{array}{c}\text { Não } \\
\text { recomendado }\end{array}$ & $\begin{array}{c}\text { Não } \\
\text { recomendado }\end{array}$ & $\begin{array}{c}\text { Não } \\
\text { recomendado }\end{array}$ & $\begin{array}{c}\text { Não } \\
\text { recomendado }\end{array}$ & $\begin{array}{c}\text { Não } \\
\text { Recomendado }\end{array}$ & $\begin{array}{c}\text { Não } \\
\text { recomendado }\end{array}$ \\
\hline $\begin{array}{l}\text { Operador } \\
\text { Grua }\end{array}$ & $\begin{array}{c}\text { Não } \\
\text { Recomendado }\end{array}$ & $\begin{array}{l}\text { Recomendado } \\
\text { parcialmente }\end{array}$ & $\begin{array}{l}\text { Não } \\
\text { recomendado }\end{array}$ & $\begin{array}{l}\text { Não } \\
\text { recomendado }\end{array}$ & $\begin{array}{l}\text { Năo } \\
\text { recomendado }\end{array}$ & $\begin{array}{c}\text { Não } \\
\text { recomendado }\end{array}$ & $\begin{array}{c}\text { Não } \\
\text { Recomendado }\end{array}$ & $\begin{array}{c}\text { Não } \\
\text { recomendado }\end{array}$ \\
\hline $\begin{array}{l}\text { Operador } \\
\text { Guincho }\end{array}$ & $\begin{array}{c}\text { Não } \\
\text { Recomendado }\end{array}$ & $\begin{array}{l}\text { Recomendado } \\
\text { parcialmente }\end{array}$ & $\begin{array}{c}\text { Não } \\
\text { recomendado }\end{array}$ & $\begin{array}{c}\text { Não } \\
\text { recomendado }\end{array}$ & $\begin{array}{c}\text { Não } \\
\text { recomendado }\end{array}$ & $\begin{array}{c}\text { Não } \\
\text { recomendado }\end{array}$ & $\begin{array}{c}\text { Não } \\
\text { Recomendado }\end{array}$ & $\begin{array}{c}\text { Não } \\
\text { recomendado }\end{array}$ \\
\hline $\begin{array}{l}\text { Operador } \\
\text { Guindaste }\end{array}$ & $\begin{array}{c}\text { Não } \\
\text { Recomendado }\end{array}$ & $\begin{array}{l}\text { Recomendado } \\
\text { parcialmente }\end{array}$ & $\begin{array}{c}\text { Não } \\
\text { recomendado }\end{array}$ & $\begin{array}{c}\text { Não } \\
\text { recomendado }\end{array}$ & $\begin{array}{c}\text { Não } \\
\text { recomendado }\end{array}$ & $\begin{array}{c}\text { Não } \\
\text { recomendado }\end{array}$ & $\begin{array}{c}\text { Não } \\
\text { Recomendado }\end{array}$ & $\begin{array}{c}\text { Não } \\
\text { recomendado }\end{array}$ \\
\hline Pedreiro & $\begin{array}{l}\text { Recomendado } \\
\text { parcialmente }\end{array}$ & $\begin{array}{l}\text { Recomendado } \\
\text { parcialmente }\end{array}$ & $\begin{array}{l}\text { Não } \\
\text { recomendado }\end{array}$ & $\begin{array}{l}\text { Não } \\
\text { recomendado }\end{array}$ & $\begin{array}{l}\text { Recomendado } \\
\text { parcialmente }\end{array}$ & $\begin{array}{l}\text { Não } \\
\text { recomendado }\end{array}$ & $\begin{array}{c}\text { Não } \\
\text { Recomendado }\end{array}$ & $\begin{array}{l}\text { Não } \\
\text { recomendado }\end{array}$ \\
\hline $\begin{array}{l}\text { Pedreiro } \\
\text { Fachada }\end{array}$ & $\begin{array}{l}\text { Recomendado } \\
\text { parcialmente }\end{array}$ & $\begin{array}{l}\text { Recomendado } \\
\text { parcialmente }\end{array}$ & $\begin{array}{c}\text { Não } \\
\text { recomendado }\end{array}$ & $\begin{array}{c}\text { Não } \\
\text { recomendado }\end{array}$ & $\begin{array}{c}\text { Não } \\
\text { Recomendado }\end{array}$ & $\begin{array}{c}\text { Não } \\
\text { recomendado }\end{array}$ & $\begin{array}{c}\text { Não } \\
\text { Recomendado }\end{array}$ & $\begin{array}{c}\text { Não } \\
\text { recomendado }\end{array}$ \\
\hline Pintor & $\begin{array}{l}\text { Recomendado } \\
\text { parcialmente }\end{array}$ & $\begin{array}{l}\text { Recomendado } \\
\text { parcialmente }\end{array}$ & $\begin{array}{c}\text { Não } \\
\text { recomendado }\end{array}$ & $\begin{array}{c}\text { Não } \\
\text { recomendado }\end{array}$ & $\begin{array}{l}\text { Recomendado } \\
\text { parcialmente }\end{array}$ & $\begin{array}{c}\text { Não } \\
\text { recomendado }\end{array}$ & $\begin{array}{c}\text { Não } \\
\text { Recomendado }\end{array}$ & $\begin{array}{c}\text { Não } \\
\text { recomendado }\end{array}$ \\
\hline Poceiro & $\begin{array}{c}\text { Não } \\
\text { Recomendado }\end{array}$ & $\begin{array}{l}\text { Recomendado } \\
\text { parcialmente }\end{array}$ & $\begin{array}{c}\text { Não } \\
\text { recomendado }\end{array}$ & $\begin{array}{c}\text { Não } \\
\text { recomendado }\end{array}$ & $\begin{array}{c}\text { Não } \\
\text { Recomendado }\end{array}$ & $\begin{array}{c}\text { Não } \\
\text { recomendado }\end{array}$ & $\begin{array}{c}\text { Não } \\
\text { Recomendado }\end{array}$ & $\begin{array}{c}\text { Não } \\
\text { recomendado }\end{array}$ \\
\hline Serralheiro & $\begin{array}{l}\text { Recomendado } \\
\text { parcialmente }\end{array}$ & $\begin{array}{l}\text { Recomendado } \\
\text { parcialmente }\end{array}$ & $\begin{array}{l}\text { Não } \\
\text { recomendado }\end{array}$ & $\begin{array}{l}\text { Não } \\
\text { recomendado }\end{array}$ & $\begin{array}{l}\text { Recomendado } \\
\text { parcialmente }\end{array}$ & $\begin{array}{c}\text { Nāo } \\
\text { recomendado }\end{array}$ & $\begin{array}{c}\text { Não } \\
\text { Recomendado }\end{array}$ & $\begin{array}{c}\text { Nāo } \\
\text { recomendado }\end{array}$ \\
\hline
\end{tabular}

Fonte: Sinduscon/SP (2015)

Buscando avaliar a viabilidade de inserção dos portadores de necessidades especiais na construção civil, foram feitas matrizes, separando por função/tipos de atividades e tipos de deficiência. Foram avaliadas as seguintes funções: Ajudante Geral, Armador, Azulejista, Carpinteiro, Eletricista, Encanador, Gesseiro, Mestre de Obras, Operador de Grua, Operador de Escavadeira, Operador de Guincho, Operador de Guindaste, Pedreiro, Pedreiro de Fachada, Pintor, Poceiro e Serralheiro. Nas matrizes são mencionadas o tipo de restrição, o local da restrição e a necessidade de adaptações. O quadro 4 ilustra a matriz de viabilidade de inserção do Ajudante Geral.

Disponível em: https://www.nucleodoconhecimento.com.br/engenharia-civil/portadores-de$\underline{\text { necessidades }}$ 
Quadro 4 - Matriz de Viabilidade de Inserção - Ajudante Geral

\begin{tabular}{|c|c|c|c|c|}
\hline $\begin{array}{l}\text { Deficiência / } \\
\text { subtipos/Atividade } \\
\text { s }\end{array}$ & $\begin{array}{l}\text { Recomendaçã } \\
\text { o }\end{array}$ & Tipo de Restrição & $\begin{array}{l}\text { Local de } \\
\text { Restriçãa } \\
0\end{array}$ & Adaptações \\
\hline \multicolumn{5}{|l|}{$\begin{array}{l}\text { Deficiência Física } \\
\text { Nanismo }\end{array}$} \\
\hline $\begin{array}{l}\text { Preparar } \\
\text { argamassa }\end{array}$ & $\begin{array}{l}\text { Recomendado } \\
\text { parcialmente }\end{array}$ & $\begin{array}{l}\text { Esforço físico e } \\
\text { empunhadura }\end{array}$ & - & Ferramenta \\
\hline $\begin{array}{l}\text { Demolir } \\
\text { edificações }\end{array}$ & $\begin{array}{l}\text { Não } \\
\text { recomendado }\end{array}$ & $\begin{array}{l}\text { Força reduzida } \\
\text { devido a } \\
\text { compleição física }\end{array}$ & - & - \\
\hline Compactar solos & $\begin{array}{l}\text { Não } \\
\text { recomendado }\end{array}$ & $\begin{array}{l}\text { Força reduzida } \\
\text { devido a } \\
\text { compleição física }\end{array}$ & & \\
\hline $\begin{array}{l}\text { Raspar e lixar } \\
\text { superfícies }\end{array}$ & $\begin{array}{l}\text { Recomendado } \\
\text { parcialmente }\end{array}$ & $\begin{array}{l}\text { Esforço físico e } \\
\text { empunhadura }\end{array}$ & $\begin{array}{l}\text { Área } \\
\text { externa } \\
\text { em } \\
\text { Balancim }\end{array}$ & $\begin{array}{l}\text { Ferramenta } \\
\text { I }\end{array}$ \\
\hline $\begin{array}{l}\text { Limpar e remover } \\
\text { resíduos }\end{array}$ & $\begin{array}{l}\text { Recomendado } \\
\text { parcialmente }\end{array}$ & $\begin{array}{l}\text { Esforço físico e } \\
\text { empunhadura }\end{array}$ & & Ferramenta \\
\hline \multicolumn{5}{|l|}{$\begin{array}{l}\text { Deficiência física } \\
\text { de membros } \\
\text { inferiores }\end{array}$} \\
\hline Paraplegia & $\begin{array}{l}\text { Não } \\
\text { recomendado }\end{array}$ & $\begin{array}{l}\text { Comprometiment } \\
\text { o total da } \\
\text { mobilidade e da } \\
\text { força }\end{array}$ & - & - \\
\hline MONOPLEGIA & $\begin{array}{l}\text { Não } \\
\text { recomendado }\end{array}$ & $\begin{array}{l}\text { Comprometiment } \\
0 \quad \text { total da }\end{array}$ & & \\
\hline
\end{tabular}

Disponível em: https://www.nucleodoconhecimento.com.br/engenharia-civil/portadores-de- 


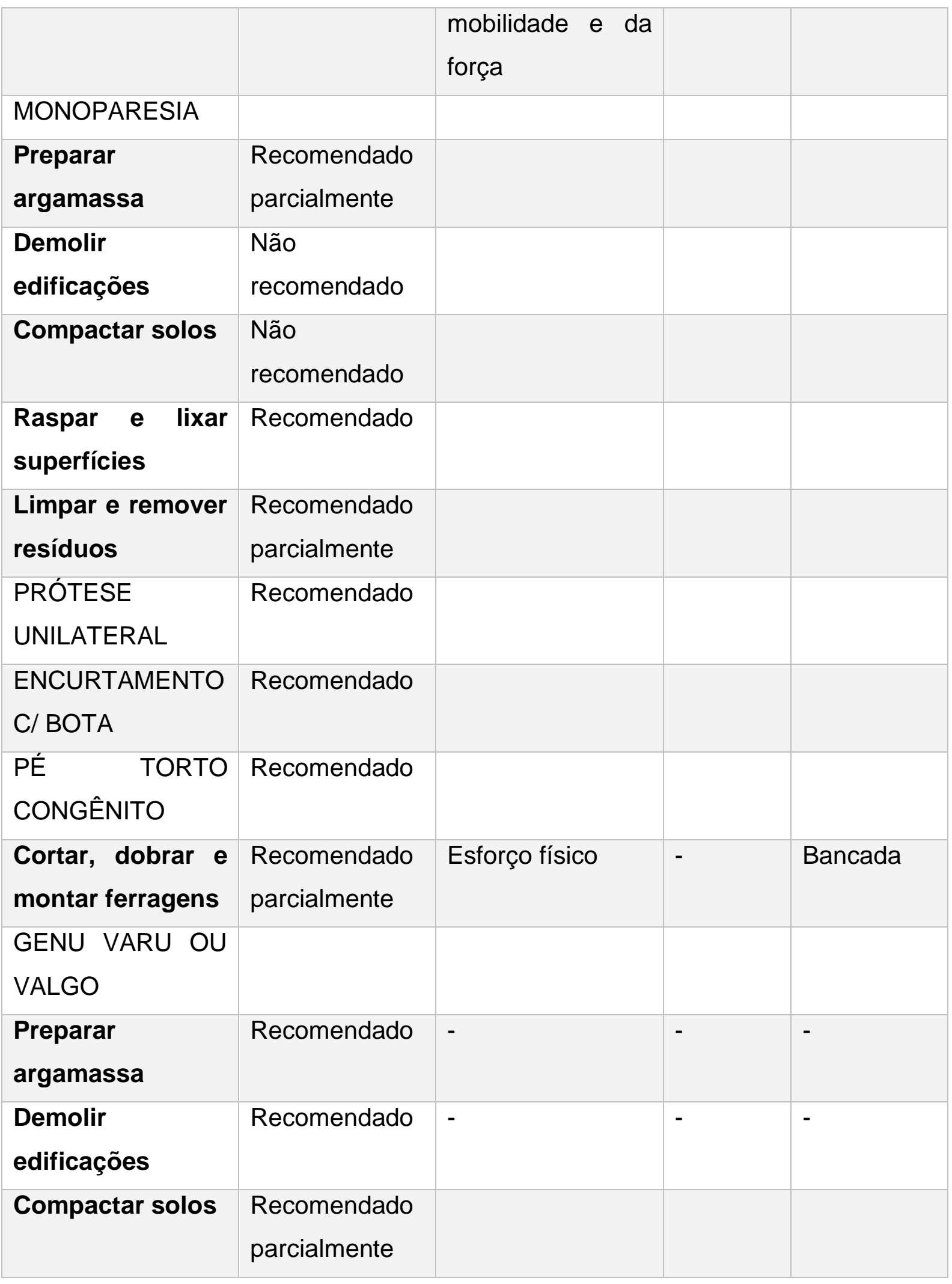

Disponível em: https://www.nucleodoconhecimento.com.br/engenharia-civil/portadores-de- 


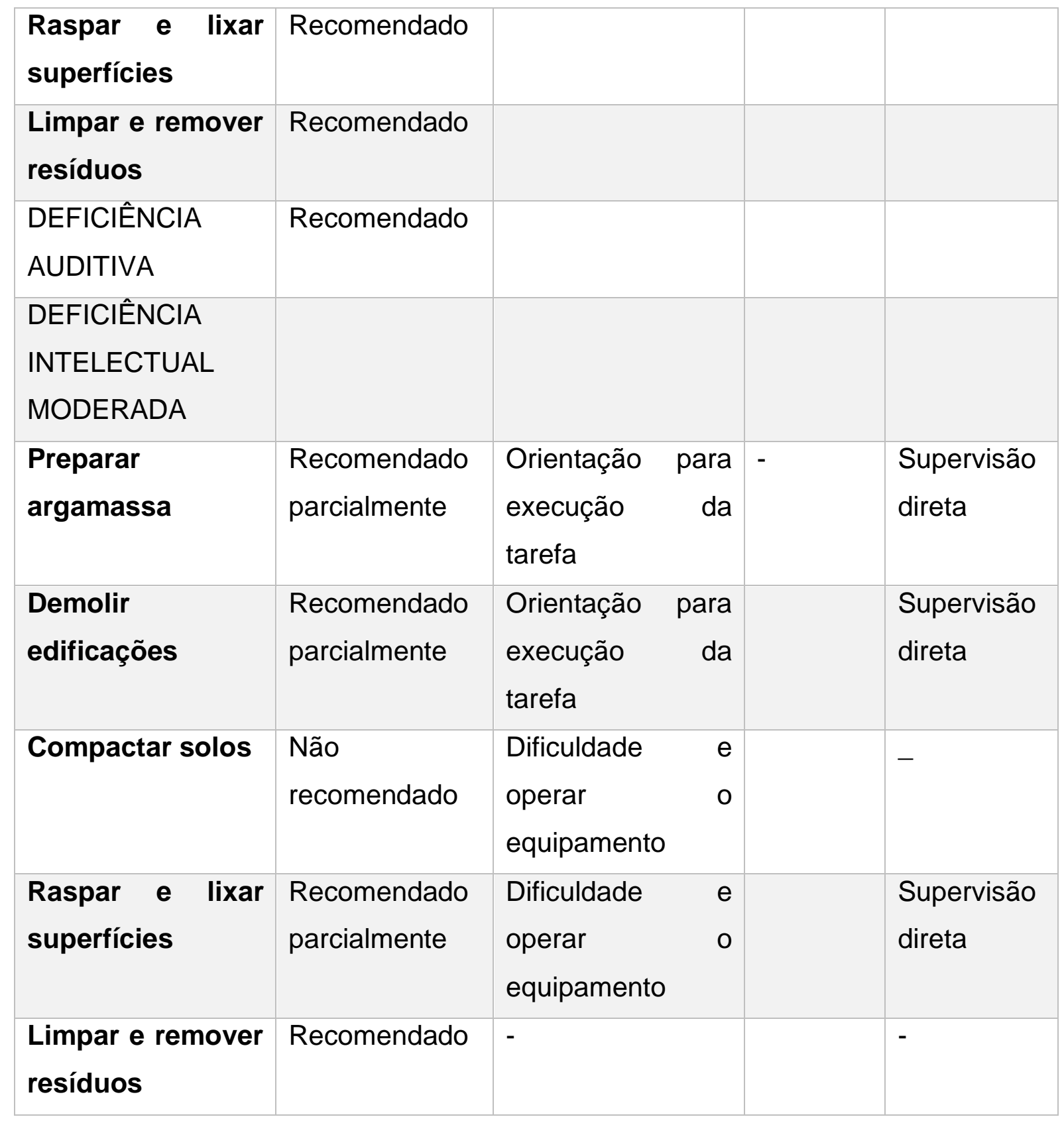

Fonte: Sinduscon/SP (2015)

O quadro 5 ilustra a matriz de viabilidade de inserção do Armador 
Quadro 5 - Matriz de Viabilidade de Inserção - Armador

\begin{tabular}{|c|c|c|c|c|}
\hline $\begin{array}{l}\text { Deficiência / } \\
\text { subtipos/Atividade } \\
\text { s }\end{array}$ & $\begin{array}{l}\text { Recomendaçã } \\
\text { O }\end{array}$ & Tipo de Restrição & $\begin{array}{l}\text { Local de } \\
\text { Restriçã } \\
\text { o }\end{array}$ & Adaptações \\
\hline \multicolumn{5}{|l|}{$\begin{array}{l}\text { Deficiência Física } \\
\text { Nanismo }\end{array}$} \\
\hline $\begin{array}{l}\text { Cortar, dobrar e } \\
\text { montar ferragens }\end{array}$ & $\begin{array}{l}\text { Recomendado } \\
\text { parcialmente }\end{array}$ & $\begin{array}{l}\text { Esforço físico e } \\
\text { empunhadura }\end{array}$ & - & Ferramental \\
\hline $\begin{array}{ll}\text { Auxiliar } & \\
\text { carpinteiro } & \text { na } \\
\text { retirada } & \text { de } \\
\text { formas } & \end{array}$ & $\begin{array}{l}\text { Não } \\
\text { recomendado }\end{array}$ & $\begin{array}{l}\text { Força reduzida } \\
\text { devido a } \\
\text { compleição física }\end{array}$ & - & - \\
\hline \multicolumn{5}{|l|}{$\begin{array}{l}\text { Deficiência física } \\
\text { de membros } \\
\text { inferiores }\end{array}$} \\
\hline Paraplegia & $\begin{array}{l}\text { Não } \\
\text { recomendado }\end{array}$ & $\begin{array}{l}\text { Comprometiment } \\
0 \quad \text { total da } \\
\text { mobilidade e da } \\
\text { força }\end{array}$ & - & - \\
\hline \multicolumn{5}{|l|}{ MONOPLEGIA } \\
\hline $\begin{array}{l}\text { Cortar, dobrar e } \\
\text { montar ferragens }\end{array}$ & $\begin{array}{l}\text { Recomendado } \\
\text { parcialmente }\end{array}$ & Esforço físico & - & $\begin{array}{l}\text { Acessibilidad } \\
\text { e específica }\end{array}$ \\
\hline $\begin{array}{l}\text { Auxiliar } \\
\text { carpinteiro na } \\
\text { retirada } \\
\text { formas }\end{array}$ & $\begin{array}{l}\text { Não } \\
\text { recomendado }\end{array}$ & $\begin{array}{l}\text { Comprometiment } \\
\text { o da mobilidade e } \\
\text { da força }\end{array}$ & - & - \\
\hline \multicolumn{5}{|l|}{$\begin{array}{l}\text { PRÓTESE } \\
\text { UNILATERAL }\end{array}$} \\
\hline $\begin{array}{l}\text { Cortar, dobrar e } \\
\text { montar ferragens }\end{array}$ & Recomendado & - & - & - \\
\hline
\end{tabular}

Disponível em: https://www.nucleodoconhecimento.com.br/engenharia-civil/portadores-de- 


\begin{tabular}{|c|c|c|c|c|}
\hline $\begin{array}{ll}\text { Auxiliar } & \\
\text { carpinteiro } & \text { na } \\
\text { retirada } & \text { de } \\
\text { formas } & \end{array}$ & Recomendado & & & \\
\hline $\begin{array}{l}\text { ENCURTAMENT } \\
\text { O C/ BOTA }\end{array}$ & & & & \\
\hline $\begin{array}{l}\text { Cortar, dobrar e } \\
\text { montar ferragens }\end{array}$ & Recomendado & & & \\
\hline $\begin{array}{l}\text { Auxiliar } \\
\text { carpinteiro na } \\
\text { retirada } \\
\text { formas }\end{array}$ & Recomendado & & & \\
\hline $\begin{array}{l}\text { PÉ TORTO } \\
\text { CONGÊNITO }\end{array}$ & & & & \\
\hline $\begin{array}{l}\text { Cortar, dobrar e } \\
\text { montar ferragens }\end{array}$ & $\begin{array}{l}\text { Recomendado } \\
\text { parcialmente }\end{array}$ & Esforço físico & - & Bancada \\
\hline $\begin{array}{ll}\text { Auxiliar } & \\
\text { carpinteiro na } \\
\text { retirada } & \text { de } \\
\text { formas } & \end{array}$ & $\begin{array}{l}\text { Recomendado } \\
\text { parcialmente }\end{array}$ & Esforço físico & - & - \\
\hline $\begin{array}{l}\text { GENU VARU OU } \\
\text { VALGO }\end{array}$ & & & & \\
\hline $\begin{array}{l}\text { Cortar, dobrar e } \\
\text { montar ferragens }\end{array}$ & Recomendado & - & - & - \\
\hline $\begin{array}{l}\text { Auxiliar } \\
\text { carpinteiro na } \\
\text { retirada das } \\
\text { formas }\end{array}$ & Recomendado & - & - & - \\
\hline $\begin{array}{l}\text { DEFICIÊNCIA } \\
\text { AUDITIVA }\end{array}$ & & & & \\
\hline
\end{tabular}




\begin{tabular}{|c|c|c|c|c|}
\hline $\begin{array}{l}\text { Cortar, dobrar e } \\
\text { montar ferragens }\end{array}$ & Recomendado & - & - & - \\
\hline $\begin{array}{ll}\text { Auxiliar } & \\
\text { carpinteiro na } \\
\text { retirada } & \text { de } \\
\text { formas } & \end{array}$ & Recomendado & - & - & - \\
\hline $\begin{array}{l}\text { DEFICIÊNCIA } \\
\text { INTELECTUAL } \\
\text { MODERADA }\end{array}$ & & & & \\
\hline $\begin{array}{l}\text { Cortar, dobrar e } \\
\text { montar ferragens }\end{array}$ & $\begin{array}{l}\text { Não } \\
\text { recomendado }\end{array}$ & $\begin{array}{l}\text { Dificuldade para } \\
\text { entender e operar } \\
\text { equipamento }\end{array}$ & - & - \\
\hline $\begin{array}{l}\text { Auxiliar } \\
\text { carpinteiro na } \\
\text { retirada } \\
\text { formas }\end{array}$ & $\begin{array}{l}\text { Recomendado } \\
\text { parcialmente }\end{array}$ & $\begin{array}{l}\text { Orientação para } \\
\text { execução da } \\
\text { tarefa }\end{array}$ & $\begin{array}{l}\text { Risco de } \\
\text { queda } \\
\text { em } \\
\text { diferente } \\
\text { s níveis }\end{array}$ & $\begin{array}{l}\text { Supervisão } \\
\text { direta }\end{array}$ \\
\hline
\end{tabular}

Fonte: Sinduscon/SP (2015)

O quadro 6 ilustra a matriz de viabilidade de inserção do Azulejista.

Quadro 6 - Matriz de Viabilidade de Inserção - Azulejista

\begin{tabular}{|l|l|l|l|l|}
\hline $\begin{array}{l}\text { Deficiência } \\
\text { subtipos/Atividade } \\
\text { s }\end{array}$ & Recomendaçã & Tipo de Restrição & $\begin{array}{l}\text { Local de } \\
\text { Restriçã }\end{array}$ & $\begin{array}{l}\text { Adaptaçõe } \\
\text { S }\end{array}$ \\
\hline $\begin{array}{l}\text { Deficiência Física } \\
\text { Nanismo }\end{array}$ & & & 0 & \\
\hline $\begin{array}{l}\text { Preparar } \\
\text { argamassa e } \\
\text { assentar azulejos }\end{array}$ & $\begin{array}{l}\text { Recomendado } \\
\text { parcialmente }\end{array}$ & $\begin{array}{l}\text { Esforço físico e } \\
\text { empunhadura }\end{array}$ & $\begin{array}{l}\text { Área } \\
\text { externa }\end{array}$ & - \\
\hline
\end{tabular}

Disponível em: https://www.nucleodoconhecimento.com.br/engenharia-civil/portadores-de- 


\begin{tabular}{|c|c|c|c|c|}
\hline $\begin{array}{l}\text { Corte de peça } \\
\text { cerâmica }\end{array}$ & Recomendado & - & - & 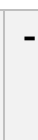 \\
\hline \multicolumn{5}{|l|}{$\begin{array}{l}\text { Deficiência física } \\
\text { de membros } \\
\text { inferiores }\end{array}$} \\
\hline Paraplegia & $\begin{array}{l}\text { Não } \\
\text { recomendado }\end{array}$ & $\begin{array}{l}\text { Comprometiment } \\
0 \quad \text { total da } \\
\text { mobilidade e da } \\
\text { força }\end{array}$ & - & - \\
\hline \multicolumn{5}{|l|}{ MONOPLEGIA } \\
\hline $\begin{array}{l}\text { Preparar } \\
\text { argamassa } \\
\text { assentar azulejos }\end{array}$ & $\begin{array}{l}\text { Recomendado } \\
\text { parcialmente }\end{array}$ & Esforço físico & $\begin{array}{l}\text { Pisos e } \\
\text { rodapés }\end{array}$ & - \\
\hline $\begin{array}{l}\text { Corte de peça } \\
\text { cerâmica }\end{array}$ & $\begin{array}{l}\text { Não } \\
\text { recomendado }\end{array}$ & $\begin{array}{l}\text { Comprometiment } \\
\text { o da mobilidade e } \\
\text { da força }\end{array}$ & - & - \\
\hline \multicolumn{5}{|l|}{$\begin{array}{l}\text { PRÓTESE } \\
\text { UNILATERAL }\end{array}$} \\
\hline $\begin{array}{l}\text { Cortar, dobrar e } \\
\text { montar ferragens }\end{array}$ & Recomendado & - & - & - \\
\hline $\begin{array}{l}\text { Auxiliar } \\
\text { carpinteiro na } \\
\text { retirada } \\
\text { formas }\end{array}$ & Recomendado & & & \\
\hline MONOPARESIA & Recomendado & - & - & - \\
\hline $\begin{array}{l}\text { PRÓTESE } \\
\text { UNILATERAL }\end{array}$ & Recomendado & - & - & - \\
\hline $\begin{array}{l}\text { ENCURTAMENTO } \\
\text { COM BOTA }\end{array}$ & Recomendado & - & - & - \\
\hline
\end{tabular}




\begin{tabular}{|c|c|c|c|c|}
\hline $\begin{array}{l}\text { PÉ TORTO } \\
\text { CONGÊNITO }\end{array}$ & Recomendado & - & - & - \\
\hline $\begin{array}{l}\text { GENU VARU OU } \\
\text { VALGO }\end{array}$ & Recomendado & - & - & - \\
\hline $\begin{array}{l}\text { DEFICIÊNCIA } \\
\text { AUDITIVA }\end{array}$ & & & & \\
\hline $\begin{array}{l}\text { Cortar, dobrar e } \\
\text { montar ferragens }\end{array}$ & Recomendado & - & - & - \\
\hline $\begin{array}{l}\text { Auxiliar } \\
\text { carpinteiro na } \\
\text { retirada } \\
\text { formas }\end{array}$ & Recomendado & - & - & - \\
\hline $\begin{array}{l}\text { DEFICIÊNCIA } \\
\text { INTELECTUAL } \\
\text { MODERADA }\end{array}$ & & & & \\
\hline $\begin{array}{l}\text { Preparar } \\
\text { argamassa } \\
\text { assentar azulejos }\end{array}$ & $\begin{array}{l}\text { Recomendado } \\
\text { parcialmente }\end{array}$ & - & - & - \\
\hline $\begin{array}{l}\text { Corte de peça } \\
\text { cerâmica }\end{array}$ & $\begin{array}{l}\text { Não } \\
\text { Recomendado }\end{array}$ & $\begin{array}{l}\text { Envolve precisão } \\
\text { e dificuldade para } \\
\text { operar } \\
\text { equipamentos }\end{array}$ & - & - \\
\hline
\end{tabular}

Fonte: Sinduscon/SP, 2015

O quadro 7 ilustra a matriz de viabilidade de inserção do Carpinteiro e o quadro 8 o do Encanador. 
Quadro 7 - Matriz de Viabilidade de Inserção - Carpinteiro

\begin{tabular}{|c|c|c|c|c|}
\hline $\begin{array}{l}\text { Deficiência } \\
\text { subtipos/Atividade } \\
\text { s }\end{array}$ & $\begin{array}{l}\text { Recomendaçã } \\
\text { o }\end{array}$ & Tipo de Restrição & $\begin{array}{l}\text { Local de } \\
\text { Restriçãa } \\
0\end{array}$ & Adaptações \\
\hline $\begin{array}{l}\text { Deficiência Física } \\
\text { Nanismo }\end{array}$ & & & & \\
\hline $\begin{array}{l}\text { Cortar peças de } \\
\text { madeira }\end{array}$ & $\begin{array}{l}\text { Recomendado } \\
\text { parcialmente }\end{array}$ & $\begin{array}{l}\text { Esforço físico e } \\
\text { empunhadura }\end{array}$ & - & Ferramental \\
\hline $\begin{array}{l}\text { Instalar batentes } \\
\text { e portas }\end{array}$ & $\begin{array}{l}\text { Não } \\
\text { recomendado }\end{array}$ & $\begin{array}{l}\text { Força reduzida } \\
\text { devido } \\
\text { compleição física }\end{array}$ & - & - \\
\hline $\begin{array}{l}\text { Separar } \\
\text { madeiras } \\
\text { pregos } \\
\text { reutilizáveis }\end{array}$ & Recomendado & & & \\
\hline $\begin{array}{l}\text { Deficiência física } \\
\text { de membros } \\
\text { inferiores }\end{array}$ & & & & \\
\hline Paraplegia & $\begin{array}{l}\text { Não } \\
\text { recomendado }\end{array}$ & $\begin{array}{l}\text { Comprometiment } \\
0 \text { total da } \\
\text { mobilidade e da } \\
\text { força }\end{array}$ & - & - \\
\hline MONOPLEGIA & $\begin{array}{l}\text { Não } \\
\text { recomendado }\end{array}$ & $\begin{array}{l}\text { Comprometiment } \\
\text { o da mobilidade e } \\
\text { a força }\end{array}$ & - & - \\
\hline \multicolumn{5}{|l|}{ MONOPARESIA } \\
\hline $\begin{array}{l}\text { Cortar peças de } \\
\text { madeira }\end{array}$ & $\begin{array}{l}\text { Recomendado } \\
\text { parcialmente }\end{array}$ & Esforço físico & $\begin{array}{l}\text { Risco de } \\
\text { quedas } \\
\text { em }\end{array}$ & - \\
\hline
\end{tabular}




\begin{tabular}{|c|c|c|c|c|}
\hline & & & $\begin{array}{l}\text { diferente } \\
\text { s níveis }\end{array}$ & \\
\hline $\begin{array}{l}\text { Instalar batentes } \\
\text { e portas }\end{array}$ & $\begin{array}{l}\text { Recomendado } \\
\text { parcialmente }\end{array}$ & Esforço físico & $\begin{array}{l}\text { Risco de } \\
\text { quedas } \\
\text { em } \\
\text { diferente } \\
\text { s níveis }\end{array}$ & - \\
\hline $\begin{array}{l}\text { Separar } \\
\text { madeiras } \\
\text { pregos } \\
\text { reutilizáveis }\end{array}$ & Recomendado & - & - & - \\
\hline \multicolumn{5}{|l|}{$\begin{array}{l}\text { PRÓTESE } \\
\text { UNILATERAL }\end{array}$} \\
\hline $\begin{array}{l}\text { Cortar peças de } \\
\text { madeira }\end{array}$ & $\begin{array}{l}\text { Recomendado } \\
\text { parcialmente }\end{array}$ & $\begin{array}{l}\text { Esforço físico e } \\
\text { equilíbrio }\end{array}$ & - & - \\
\hline $\begin{array}{l}\text { Instalar batentes } \\
\text { e portas }\end{array}$ & $\begin{array}{l}\text { Recomendado } \\
\text { parcialmente }\end{array}$ & $\begin{array}{l}\text { Esforço físico e } \\
\text { equilíbrio }\end{array}$ & - & \\
\hline $\begin{array}{l}\text { Separar } \\
\text { madeiras } \\
\text { pregos } \\
\text { reutilizáveis }\end{array}$ & Recomendado & - & - & - \\
\hline $\begin{array}{l}\text { ENCURTAMENT } \\
\text { O C/ BOTA }\end{array}$ & Recomendado & & & \\
\hline \multicolumn{5}{|l|}{$\begin{array}{l}\text { PÉ TORTO } \\
\text { CONGÊNITO }\end{array}$} \\
\hline $\begin{array}{l}\text { Cortar peças de } \\
\text { madeira }\end{array}$ & $\begin{array}{l}\text { Recomendado } \\
\text { parcialmente }\end{array}$ & Esforço físico & - & Bancada \\
\hline $\begin{array}{l}\text { Instalar batentes } \\
\text { e portas }\end{array}$ & $\begin{array}{l}\text { Recomendado } \\
\text { parcialmente }\end{array}$ & Esforço físico & - & - \\
\hline
\end{tabular}

Disponível em: https://www.nucleodoconhecimento.com.br/engenharia-civil/portadores-de$\underline{\text { necessidades }}$ 


\begin{tabular}{|c|c|c|c|c|}
\hline $\begin{array}{l}\text { Separar } \\
\text { madeiras } \\
\text { pregos } \\
\text { reutilizáveis }\end{array}$ & Recomendado & - & - & - \\
\hline \multicolumn{5}{|l|}{$\begin{array}{l}\text { GENU VARU OU } \\
\text { VALGO }\end{array}$} \\
\hline $\begin{array}{l}\text { Cortar peças de } \\
\text { madeira }\end{array}$ & $\begin{array}{l}\text { Recomendado } \\
\text { parcialmente }\end{array}$ & Esforço físico & - & - \\
\hline $\begin{array}{l}\text { Instalar batentes } \\
\text { e portas }\end{array}$ & $\begin{array}{l}\text { Recomendado } \\
\text { parcialmente }\end{array}$ & Esforço físico & - & - \\
\hline $\begin{array}{l}\text { Separar } \\
\text { madeiras } \\
\text { pregos } \\
\text { reutilizáveis }\end{array}$ & Recomendado & - & - & - \\
\hline \multicolumn{5}{|l|}{$\begin{array}{l}\text { DEFICIÊNCIA } \\
\text { AUDITIVA }\end{array}$} \\
\hline $\begin{array}{l}\text { Cortar peças de } \\
\text { madeira }\end{array}$ & Recomendado & - & - & - \\
\hline $\begin{array}{l}\text { Instalar batentes } \\
\text { e portas }\end{array}$ & $\begin{array}{l}\text { Recomendado } \\
\text { parcialmente }\end{array}$ & $\begin{array}{l}\text { Comunicação à } \\
\text { distância }\end{array}$ & - & $\begin{array}{l}\text { Acessibilidade } \\
\text { comunicacion } \\
\text { al }\end{array}$ \\
\hline $\begin{array}{l}\text { Separar } \\
\text { madeiras } \\
\text { pregos } \\
\text { reutilizáveis }\end{array}$ & Recomendado & - & - & - \\
\hline \multicolumn{5}{|l|}{$\begin{array}{l}\text { DEFICIÊNCIA } \\
\text { INTELECTUAL } \\
\text { MODERADA }\end{array}$} \\
\hline $\begin{array}{l}\text { Cortar peças de } \\
\text { madeira }\end{array}$ & $\begin{array}{l}\text { Não } \\
\text { recomendado }\end{array}$ & $\begin{array}{l}\text { Envolve precisão } \\
\text { e dificuldade para }\end{array}$ & - & - \\
\hline
\end{tabular}




\begin{tabular}{|l|l|l|l|l|}
\hline & & $\begin{array}{l}\text { operar } \\
\text { equipamentos }\end{array}$ & \\
\hline $\begin{array}{l}\text { Instalar batentes } \\
\text { e portas }\end{array}$ & $\begin{array}{l}\text { Não } \\
\text { Recomendado }\end{array}$ & $\begin{array}{l}\text { Envolve precisão } \\
\text { e dificuldade para } \\
\text { operar }\end{array}$ & - \\
\hline $\begin{array}{l}\text { Separar } \\
\text { equipamentos }\end{array}$ & \\
\hline $\begin{array}{l}\text { madeiras } \\
\text { pregos } \\
\text { reutilizáveis }\end{array}$ & e & & - & - \\
\hline
\end{tabular}

Fonte: Sinduscon/SP (2015)

Quadro 8 - Matriz de Viabilidade de Inserção - Encanador

\begin{tabular}{|c|c|c|c|c|}
\hline $\begin{array}{l}\text { Deficiência } \\
\text { subtipos/Atividade } \\
\text { s }\end{array}$ & $\begin{array}{l}\text { Recomendaçã } \\
\text { o }\end{array}$ & Tipo de Restrição & $\begin{array}{l}\text { Local de } \\
\text { Restriçã } \\
0\end{array}$ & Adaptações \\
\hline $\begin{array}{l}\text { Deficiência Física } \\
\text { Nanismo }\end{array}$ & & & & \\
\hline $\begin{array}{l}\text { Recortar parede } \\
\text { e instalar } \\
\text { tubulação }\end{array}$ & $\begin{array}{l}\text { Recomendado } \\
\text { parcialmente }\end{array}$ & $\begin{array}{l}\text { Esforço físico e } \\
\text { empunhadura }\end{array}$ & $\begin{array}{l}\text { Trabalho } \\
\text { externo } \\
\text { em altura } \\
\text { e } \\
\text { andaime } \\
\text { s }\end{array}$ & Ferramental \\
\hline $\begin{array}{lr}\text { Cortar } & \text { tubos } \\
\text { com } & \text { serra } \\
\text { manual } & \end{array}$ & Recomendado & - & - & - \\
\hline
\end{tabular}




\begin{tabular}{|c|c|c|c|c|}
\hline $\begin{array}{l}\text { Deficiência física } \\
\text { de membros } \\
\text { inferiores }\end{array}$ & & & & \\
\hline Paraplegia & $\begin{array}{l}\text { Não } \\
\text { recomendado }\end{array}$ & $\begin{array}{l}\text { Comprometiment } \\
\text { o total da } \\
\text { mobilidade e da } \\
\text { força }\end{array}$ & - & - \\
\hline MONOPLEGIA & $\begin{array}{l}\text { Não } \\
\text { recomendado }\end{array}$ & $\begin{array}{l}\text { Comprometiment } \\
\text { o da mobilidade e } \\
\text { a força }\end{array}$ & - & - \\
\hline MONOPARESIA & & & & \\
\hline $\begin{array}{l}\text { Recortar parede } \\
\text { e instalar } \\
\text { tubulação }\end{array}$ & $\begin{array}{l}\text { Recomendado } \\
\text { parcialmente }\end{array}$ & Esforço físico & $\begin{array}{l}\text { Risco de } \\
\text { quedas } \\
\text { em } \\
\text { diferente } \\
\text { s níveis }\end{array}$ & - \\
\hline $\begin{array}{ll}\text { Cortar } & \text { tubos } \\
\text { com } & \text { serra } \\
\text { manual } & \end{array}$ & $\begin{array}{l}\text { Recomendado } \\
\text { parcialmente }\end{array}$ & Esforço físico & $\begin{array}{l}\text { Risco de } \\
\text { quedas } \\
\text { em } \\
\text { diferente } \\
\text { s níveis }\end{array}$ & - \\
\hline $\begin{array}{l}\text { PRÓTESE } \\
\text { UNILATERAL }\end{array}$ & & & & \\
\hline $\begin{array}{l}\text { Recortar parede } \\
\text { e instalar } \\
\text { tubulação }\end{array}$ & $\begin{array}{l}\text { Recomendado } \\
\text { parcialmente }\end{array}$ & $\begin{array}{l}\text { Esforço físico e } \\
\text { equilíbrio }\end{array}$ & - & - \\
\hline $\begin{array}{ll}\text { Cortar } & \text { tubos } \\
\text { com } & \text { serra } \\
\text { manual } & \end{array}$ & $\begin{array}{l}\text { Recomendado } \\
\text { parcialmente }\end{array}$ & $\begin{array}{l}\text { Esforço físico e } \\
\text { equilíbrio }\end{array}$ & - & \\
\hline
\end{tabular}

Disponível em: https://www.nucleodoconhecimento.com.br/engenharia-civil/portadores-de- 


\begin{tabular}{|c|c|c|c|c|}
\hline $\begin{array}{l}\text { ENCURTAMENT } \\
\text { O C/ BOTA }\end{array}$ & Recomendado & & & \\
\hline $\begin{array}{l}\text { PÉ TORTO } \\
\text { CONGÊNITO }\end{array}$ & & & & \\
\hline $\begin{array}{l}\text { Recortar parede } \\
\text { e instalar } \\
\text { tubulação }\end{array}$ & $\begin{array}{l}\text { Recomendado } \\
\text { parcialmente }\end{array}$ & Esforço físico & - & Bancada \\
\hline $\begin{array}{ll}\text { Cortar tubos } \\
\text { com } \\
\text { manual }\end{array}$ & $\begin{array}{l}\text { Recomendado } \\
\text { parcialmente }\end{array}$ & Esforço físico & - & - \\
\hline $\begin{array}{l}\text { GENU VARU OU } \\
\text { VALGO }\end{array}$ & & & & \\
\hline $\begin{array}{l}\text { Recortar parede } \\
\text { e instalar } \\
\text { tubulação }\end{array}$ & $\begin{array}{l}\text { Recomendado } \\
\text { parcialmente }\end{array}$ & $\begin{array}{l}\text { Esforço físico e } \\
\text { mobilidade } \\
\text { reduzida }\end{array}$ & $\begin{array}{l}\text { Trabalho } \\
\text { Externo } \\
\text { em altura }\end{array}$ & - \\
\hline $\begin{array}{ll}\text { Cortar } & \text { tubos } \\
\text { com } & \text { serra } \\
\text { manual } & \end{array}$ & Recomendado & - & - & - \\
\hline $\begin{array}{l}\text { DEFICIÊNCIA } \\
\text { AUDITIVA }\end{array}$ & & & & \\
\hline $\begin{array}{l}\text { Recortar parede } \\
\text { e instalar } \\
\text { tubulação }\end{array}$ & $\begin{array}{l}\text { Recomendado } \\
\text { parcialmente }\end{array}$ & $\begin{array}{l}\text { Comunicação à } \\
\text { distância }\end{array}$ & $\begin{array}{l}\text { Fora do } \\
\text { alcance } \\
\text { visual }\end{array}$ & $\begin{array}{l}\text { Acessibilidade } \\
\text { comunicacion } \\
\text { al }\end{array}$ \\
\hline $\begin{array}{ll}\text { Cortar } & \text { tubos } \\
\text { com } & \text { serra } \\
\text { manual } & \end{array}$ & Recomendado & - & - & - \\
\hline $\begin{array}{l}\text { DEFICIÊNCIA } \\
\text { INTELECTUAL } \\
\text { MODERADA }\end{array}$ & $\begin{array}{l}\text { Não } \\
\text { recomendado }\end{array}$ & $\begin{array}{l}\text { Envolve precisão } \\
\text { e dificuldade para } \\
\text { operar } \\
\text { equipamentos }\end{array}$ & & \\
\hline
\end{tabular}

Disponível em: https://www.nucleodoconhecimento.com.br/engenharia-civil/portadores-de- 
Fonte: Sinduscon/SP (2015)

O quadro 9 ilustra a matriz de viabilidade de inserção do Eletricista e o quadro 10 a do Gesseiro.

Quadro 9 - Matriz de Viabilidade de Inserção - Eletricista

\begin{tabular}{|c|c|c|c|c|}
\hline $\begin{array}{l}\text { Deficiência / } \\
\text { subtipos/Atividade } \\
\text { s }\end{array}$ & $\begin{array}{l}\text { Recomendaçã } \\
\text { O }\end{array}$ & Tipo de Restrição & $\begin{array}{l}\text { Local de } \\
\text { Restriçãa } \\
0\end{array}$ & Adaptações \\
\hline \multicolumn{5}{|l|}{$\begin{array}{l}\text { Deficiência Física } \\
\text { Nanismo }\end{array}$} \\
\hline $\begin{array}{l}\text { Passar fiação e } \\
\text { instalar quadros }\end{array}$ & $\begin{array}{l}\text { Recomendado } \\
\text { parcialmente }\end{array}$ & Esforço físico & $\begin{array}{l}\text { Passar } \\
\text { fiação } \\
\text { em shaft }\end{array}$ & - \\
\hline $\begin{array}{l}\text { Energizar rede } \\
\text { elétrica } \\
\text { executar testes }\end{array}$ & $\begin{array}{l}\text { Recomendado } \\
\text { parcialmente }\end{array}$ & Esforço físico & $\begin{array}{l}\text { Cabine } \\
\text { primária }\end{array}$ & - \\
\hline \multicolumn{5}{|l|}{$\begin{array}{l}\text { Deficiência física } \\
\text { de membros } \\
\text { inferiores }\end{array}$} \\
\hline Paraplegia & $\begin{array}{l}\text { Não } \\
\text { recomendado }\end{array}$ & $\begin{array}{l}\text { Comprometiment } \\
0 \quad \text { total da } \\
\text { mobilidade e da } \\
\text { força }\end{array}$ & - & - \\
\hline MONOPLEGIA & $\begin{array}{l}\text { Não } \\
\text { recomendado }\end{array}$ & $\begin{array}{l}\text { Comprometiment } \\
\text { o da mobilidade e } \\
\text { a força }\end{array}$ & - & - \\
\hline MONOPARESIA & $\begin{array}{l}\text { Não } \\
\text { recomendado }\end{array}$ & $\begin{array}{l}\text { Redução da } \\
\text { mobilidade e da } \\
\text { força }\end{array}$ & & \\
\hline
\end{tabular}

Disponível em: https://www.nucleodoconhecimento.com.br/engenharia-civil/portadores-de- 


\begin{tabular}{|c|c|c|c|c|}
\hline $\begin{array}{l}\text { PRÓTESE } \\
\text { UNILATERAL } \\
\text { (exceto prótese } \\
\text { metálica) }\end{array}$ & Recomendado & & & \\
\hline $\begin{array}{l}\text { ENCURTAMENT } \\
\text { O C/ BOTA }\end{array}$ & Recomendado & & & \\
\hline $\begin{array}{l}\text { PÉ TORTO } \\
\text { CONGÊNITO }\end{array}$ & & & & \\
\hline $\begin{array}{l}\text { Passar fiação e } \\
\text { instalar quadros }\end{array}$ & $\begin{array}{l}\text { Recomendado } \\
\text { parcialmente }\end{array}$ & Esforço físico & $\begin{array}{l}\text { Altura } \\
\text { em área } \\
\text { externa }\end{array}$ & - \\
\hline $\begin{array}{l}\text { Energizar rede } \\
\text { elétrica } \\
\text { executar testes }\end{array}$ & $\begin{array}{l}\text { Recomendado } \\
\text { parcialmente }\end{array}$ & Esforço físico & $\begin{array}{l}\text { Cabine } \\
\text { primária }\end{array}$ & - \\
\hline $\begin{array}{l}\text { GENU VARU OU } \\
\text { VALGO }\end{array}$ & & & & \\
\hline $\begin{array}{l}\text { Passar fiação e } \\
\text { instalar quadros }\end{array}$ & Recomendado & - & - & - \\
\hline $\begin{array}{lr}\text { Energizar rede } \\
\text { elétrica } \\
\text { executar testes }\end{array}$ & Recomendado & - & - & - \\
\hline $\begin{array}{l}\text { DEFICIÊNCIA } \\
\text { AUDITIVA }\end{array}$ & & & & \\
\hline Passar fiação & $\begin{array}{l}\text { Recomendado } \\
\text { parcialmente }\end{array}$ & $\begin{array}{l}\text { Comunicação à } \\
\text { distância }\end{array}$ & $\begin{array}{l}\text { Fora do } \\
\text { alcance } \\
\text { visual }\end{array}$ & $\begin{array}{l}\text { Acessibilidade } \\
\text { comunicacion } \\
\text { al }\end{array}$ \\
\hline Instalar quadros & Recomendado & & & \\
\hline $\begin{array}{l}\text { Energizar rede } \\
\text { elétrica } \\
\text { executar testes }\end{array}$ & $\begin{array}{l}\text { Recomendado } \\
\text { parcialmente }\end{array}$ & $\begin{array}{l}\text { Comunicação à } \\
\text { distância }\end{array}$ & $\begin{array}{l}\text { Fora do } \\
\text { alcance } \\
\text { visual }\end{array}$ & $\begin{array}{l}\text { Acessibilidade } \\
\text { comunicacion } \\
\text { al }\end{array}$ \\
\hline
\end{tabular}




\begin{tabular}{|l|l|l|l|l|}
\hline $\begin{array}{l}\text { DEFICIÉNCIA } \\
\text { INTELECTUAL } \\
\text { MODERADA }\end{array}$ & & & \\
$\begin{array}{l}\text { Passar fiação e } \\
\text { instalar quadros }\end{array}$ & $\begin{array}{l}\text { Não } \\
\text { recomendado }\end{array}$ & $\begin{array}{l}\text { Dificuldade para } \\
\text { entender e } \\
\text { executar tarefas }\end{array}$ & \\
\hline $\begin{array}{l}\text { Energizar rede } \\
\text { elétrica Não }\end{array}$ & $\begin{array}{l}\text { Dificuldade para } \\
\text { executar testes }\end{array}$ & $\begin{array}{l}\text { recomendado } \\
\text { entender ex } \\
\text { executar tarefas }\end{array}$ & \\
\hline
\end{tabular}

Fonte: Sinduscon/SP (2015)

Os quadros 10, 11 e 12 ilustram a matriz de viabilidade de inserção do Gesseiro, Mestre de Obras e operador de grua, respectivamente.

Quadro 10 - Matriz de Viabilidade de Inserção - Gesseiro

\begin{tabular}{|c|c|c|c|c|}
\hline $\begin{array}{l}\text { Deficiência / } \\
\text { subtipos/Atividade } \\
\text { s }\end{array}$ & $\begin{array}{l}\text { Recomendaçã } \\
\text { o }\end{array}$ & Tipo de Restrição & $\begin{array}{l}\text { Local de } \\
\text { Restriçã } \\
0\end{array}$ & Adaptações \\
\hline $\begin{array}{l}\text { Deficiência Física } \\
\text { Nanismo }\end{array}$ & $\begin{array}{l}\text { Recomendado } \\
\text { parcialmente }\end{array}$ & Esforço físico & $\begin{array}{l}\text { Trabalho } \\
\text { em altura }\end{array}$ & $\begin{array}{l}\text { Ferramenta } \\
\text { I }\end{array}$ \\
\hline $\begin{array}{l}\text { Deficiência física } \\
\text { de membros } \\
\text { inferiores }\end{array}$ & & & & \\
\hline Paraplegia & $\begin{array}{l}\text { Não } \\
\text { recomendado }\end{array}$ & $\begin{array}{l}\text { Comprometiment } \\
0 \quad \text { total da } \\
\text { mobilidade e da } \\
\text { força }\end{array}$ & - & - \\
\hline MONOPLEGIA & $\begin{array}{l}\text { Não } \\
\text { recomendado }\end{array}$ & $\begin{array}{l}\text { Comprometiment } \\
\text { o da mobilidade e } \\
\text { a força }\end{array}$ & - & - \\
\hline
\end{tabular}

Disponível em: https://www.nucleodoconhecimento.com.br/engenharia-civil/portadores-de- 


\begin{tabular}{|c|c|c|c|c|}
\hline MONOPARESIA & $\begin{array}{l}\text { Não } \\
\text { recomendado }\end{array}$ & $\begin{array}{l}\text { Redução } \\
\text { mobilidade e da } \\
\text { força }\end{array}$ & & \\
\hline $\begin{array}{l}\text { PRÓTESE } \\
\text { UNILATERAL }\end{array}$ & Recomendado & & & \\
\hline $\begin{array}{l}\text { ENCURTAMENTO } \\
\text { C/ BOTA }\end{array}$ & Recomendado & & & \\
\hline $\begin{array}{l}\text { PÉ TORTO } \\
\text { CONGÊNITO }\end{array}$ & $\begin{array}{l}\text { Recomendado } \\
\text { parcialmente }\end{array}$ & $\begin{array}{l}\text { Dependendo do } \\
\text { grau }\end{array}$ & & \\
\hline $\begin{array}{l}\text { GENU VARU OU } \\
\text { VALGO }\end{array}$ & $\begin{array}{l}\text { Recomendado } \\
\text { parcialmente }\end{array}$ & $\begin{array}{l}\text { Dependendo do } \\
\text { grau }\end{array}$ & & \\
\hline $\begin{array}{l}\text { DEFICIÊNCIA } \\
\text { AUDITIVA }\end{array}$ & Recomendado & & & \\
\hline $\begin{array}{l}\text { DEFICIÊNCIA } \\
\text { INTELECTUAL } \\
\text { MODERADA }\end{array}$ & $\begin{array}{l}\text { Não } \\
\text { recomendado }\end{array}$ & $\begin{array}{l}\text { Envolve precisão } \\
\text { e dificuldade em } \\
\text { operar } \\
\text { equipamentos }\end{array}$ & - & - \\
\hline
\end{tabular}

Fonte: Sinduscon/SP (2015)

Quadro 11 - Matriz de Viabilidade de Inserção - Mestre de Obras

\begin{tabular}{|l|l|l|l|l|}
\hline $\begin{array}{l}\text { Deficiência } \\
\text { subtipos/Atividade } \\
\text { S }\end{array}$ & $\begin{array}{l}\text { Recomendaçã } \\
\text { Deficiência Física } \\
\text { Nanismo }\end{array}$ & Tipo de Restrição & $\begin{array}{l}\text { Local de } \\
\text { Restriçã }\end{array}$ & $\begin{array}{l}\text { Adaptaçõe } \\
\text { S }\end{array}$ \\
\hline $\begin{array}{l}\text { Planejamento } \\
\text { Inspeção de } \\
\text { qualidade }\end{array}$ & $\begin{array}{l}\text { Recomendado } \\
\text { pecomendado } \\
\text { parcialmente }\end{array}$ & Mobilidade & Escadas & - \\
\hline
\end{tabular}

Disponível em: https://www.nucleodoconhecimento.com.br/engenharia-civil/portadores-de- 


\begin{tabular}{|c|c|c|c|c|}
\hline $\begin{array}{l}\text { Deficiência física } \\
\text { de membros } \\
\text { inferiores }\end{array}$ & & & & \\
\hline PARAPLEGIA & & & - & - \\
\hline Planejamento & Recomendado & & & \\
\hline $\begin{array}{l}\text { Inspeção de } \\
\text { qualidade }\end{array}$ & $\begin{array}{l}\text { Não } \\
\text { recomendado }\end{array}$ & $\begin{array}{l}\text { Comprometiment } \\
\text { o da mobilidade }\end{array}$ & & \\
\hline MONOPLEGIA & & & - & - \\
\hline Planejamento & Recomendado & & & \\
\hline $\begin{array}{l}\text { Inspeção de } \\
\text { qualidade }\end{array}$ & $\begin{array}{l}\text { Não } \\
\text { recomendado }\end{array}$ & $\begin{array}{l}\text { Comprometiment } \\
\text { o da mobilidade }\end{array}$ & - & - \\
\hline MONOPARESIA & & & & \\
\hline Planejamento & Recomendado & & & \\
\hline $\begin{array}{l}\text { Inspeção de } \\
\text { qualidade }\end{array}$ & $\begin{array}{l}\text { Não } \\
\text { recomendado }\end{array}$ & $\begin{array}{l}\text { Comprometiment } \\
\text { o da mobilidade }\end{array}$ & - & - \\
\hline $\begin{array}{l}\text { PRÓTESE } \\
\text { UNILATERAL }\end{array}$ & Recomendado & & & \\
\hline $\begin{array}{l}\text { ENCURTAMENTO } \\
\text { C/ BOTA }\end{array}$ & Recomendado & & & \\
\hline $\begin{array}{l}\text { PÉ TORTO } \\
\text { CONGÊNITO }\end{array}$ & & & & \\
\hline Planejamento & Recomendado & - & - & - \\
\hline $\begin{array}{l}\text { Inspeção de } \\
\text { qualidade }\end{array}$ & $\begin{array}{l}\text { Recomendado } \\
\text { parcialmente }\end{array}$ & $\begin{array}{l}\text { Mobilidade } \\
\text { reduzida }\end{array}$ & - & - \\
\hline $\begin{array}{l}\text { GENU VARU OU } \\
\text { VALGO }\end{array}$ & & & & \\
\hline Planejamento & Recomendado & - & - & - \\
\hline $\begin{array}{l}\text { Inspeção de } \\
\text { qualidade }\end{array}$ & $\begin{array}{l}\text { Recomendado } \\
\text { parcialmente }\end{array}$ & $\begin{array}{l}\text { Mobilidade } \\
\text { Reduzida }\end{array}$ & - & - \\
\hline
\end{tabular}

Disponível em: https://www.nucleodoconhecimento.com.br/engenharia-civil/portadores-de- 


\begin{tabular}{|l|l|l|l|l|}
\hline $\begin{array}{l}\text { DEFICIÊNCIA } \\
\text { AUDITIVA }\end{array}$ & & & \\
\hline $\begin{array}{l}\text { Planejamento } \\
\text { Inspeção de }\end{array}$ & $\begin{array}{l}\text { Rão } \\
\text { qualidade }\end{array}$ & Recomendado & - & - \\
\hline $\begin{array}{l}\text { DEFICIÊNCIA } \\
\text { INTELECTUAL } \\
\text { MODERADA }\end{array}$ & $\begin{array}{l}\text { Não } \\
\text { recomendado }\end{array}$ & $\begin{array}{l}\text { Comunicação } \\
\text { entender }\end{array}$ & \\
\hline
\end{tabular}

Fonte: Sinduscon/SP (2015)

Quadro 12 - Matriz de Viabilidade de Inserção - Operador de Grua

\begin{tabular}{|c|c|c|c|c|}
\hline $\begin{array}{l}\text { Deficiência / } \\
\text { subtipos/Atividade } \\
\text { s }\end{array}$ & $\begin{array}{l}\text { Recomendaçã } \\
\text { o }\end{array}$ & Tipo de Restrição & $\begin{array}{l}\text { Local de } \\
\text { Restriçãa } \\
0\end{array}$ & Adaptações \\
\hline $\begin{array}{l}\text { Deficiência Física } \\
\text { Nanismo }\end{array}$ & $\begin{array}{l}\text { Não } \\
\text { recomendado }\end{array}$ & $\begin{array}{l}\text { Impossibilidade } \\
\text { de operação de } \\
\text { equipamentos } \\
\text { devido a } \\
\text { compleição física }\end{array}$ & & $\begin{array}{l}\text { Demanda } \\
\text { adaptação em } \\
\text { equipamentos } \\
\text {, geralmente } \\
\text { de terceiros }\end{array}$ \\
\hline \multicolumn{5}{|l|}{$\begin{array}{l}\text { Deficiência física } \\
\text { de membros } \\
\text { inferiores }\end{array}$} \\
\hline PARAPLEGIA & $\begin{array}{l}\text { Não } \\
\text { recomendado }\end{array}$ & $\begin{array}{l}\text { Comprometiment } \\
0 \quad \text { total da } \\
\text { mobilidade e da } \\
\text { força }\end{array}$ & - & $\begin{array}{l}\text { Demanda } \\
\text { adaptação em } \\
\text { equipamentos } \\
\text {, geralmente } \\
\text { de terceiros }\end{array}$ \\
\hline
\end{tabular}

Disponível em: https://www.nucleodoconhecimento.com.br/engenharia-civil/portadores-de- 


\begin{tabular}{|c|c|c|c|c|}
\hline MONOPLEGIA & $\begin{array}{l}\text { Não } \\
\text { recomendado }\end{array}$ & $\begin{array}{l}\text { Comprometiment } \\
\text { o da mobilidade e } \\
\text { da força }\end{array}$ & - & $\begin{array}{l}\text { Demanda } \\
\text { adaptação em } \\
\text { equipamentos } \\
\text {, geralmente } \\
\text { de terceiros }\end{array}$ \\
\hline MONOPARESIA & $\begin{array}{l}\text { Não } \\
\text { recomendado }\end{array}$ & $\begin{array}{l}\text { Redução da } \\
\text { mobilidade e da } \\
\text { força }\end{array}$ & - & $\begin{array}{l}\text { Demanda } \\
\text { adaptação em } \\
\text { equipamentos } \\
\text {, geralmente } \\
\text { de terceiros }\end{array}$ \\
\hline $\begin{array}{l}\text { PRÓTESE } \\
\text { UNILATERAL }\end{array}$ & Recomendado & & & \\
\hline $\begin{array}{l}\text { ENCURTAMENT } \\
\text { O C/ BOTA }\end{array}$ & Recomendado & & & \\
\hline $\begin{array}{l}\text { PÉ TORTO } \\
\text { CONGÊNITO }\end{array}$ & $\begin{array}{l}\text { Não } \\
\text { recomendado }\end{array}$ & $\begin{array}{l}\text { Redução da } \\
\text { mobilidade }\end{array}$ & - & $\begin{array}{l}\text { Acesso a } \\
\text { cabine }\end{array}$ \\
\hline $\begin{array}{l}\text { GENU VARU OU } \\
\text { VALGO }\end{array}$ & $\begin{array}{l}\text { Não } \\
\text { recomendado }\end{array}$ & $\begin{array}{l}\text { Redução da } \\
\text { mobilidade }\end{array}$ & - & $\begin{array}{l}\text { Acesso a } \\
\text { cabine }\end{array}$ \\
\hline $\begin{array}{l}\text { DEFICIÊNCIA } \\
\text { AUDITIVA }\end{array}$ & $\begin{array}{l}\text { Não } \\
\text { recomendado }\end{array}$ & $\begin{array}{l}\text { Demanda } \\
\text { radiocomunicaçã } \\
\text { o }\end{array}$ & - & - \\
\hline $\begin{array}{l}\text { DEFICIÊNCIA } \\
\text { INTELECTUAL } \\
\text { MODERADA }\end{array}$ & $\begin{array}{l}\text { Não } \\
\text { recomendado }\end{array}$ & $\begin{array}{l}\text { Dificuldade para } \\
\text { entender e operar } \\
\text { equipamento }\end{array}$ & - & - \\
\hline
\end{tabular}

Fonte: Sinduscon/SP (2015)

O quadro 13 ilustra a matriz de viabilidade de inserção do Operador de Escavadeira e o quadro 14 a do Operador de Guincho. 
Quadro 13 - Matriz de Viabilidade de Inserção - Operador de Escavadeira

\begin{tabular}{|c|c|c|c|c|}
\hline $\begin{array}{l}\text { Deficiência / } \\
\text { subtipos/Atividade } \\
\text { s }\end{array}$ & $\begin{array}{l}\text { Recomendaçã } \\
\text { o }\end{array}$ & Tipo de Restrição & $\begin{array}{l}\text { Local de } \\
\text { Restriçãa } \\
0\end{array}$ & Adaptações \\
\hline $\begin{array}{l}\text { Deficiência Física } \\
\text { Nanismo }\end{array}$ & $\begin{array}{l}\text { Não } \\
\text { recomendado }\end{array}$ & $\begin{array}{l}\text { Impossibilidade } \\
\text { de operação de } \\
\text { equipamentos } \\
\text { devido a } \\
\text { compleição física }\end{array}$ & & $\begin{array}{l}\text { Demanda } \\
\text { adaptação em } \\
\text { equipamentos } \\
\text {, geralmente } \\
\text { de terceiros }\end{array}$ \\
\hline \multicolumn{5}{|l|}{$\begin{array}{l}\text { Deficiência física } \\
\text { de membros } \\
\text { inferiores }\end{array}$} \\
\hline PARAPLEGIA & $\begin{array}{l}\text { Não } \\
\text { recomendado }\end{array}$ & $\begin{array}{l}\text { Comprometiment } \\
0 \text { total da } \\
\text { mobilidade e da } \\
\text { força }\end{array}$ & - & $\begin{array}{l}\text { Demanda } \\
\text { adaptação em } \\
\text { equipamentos } \\
\text { geralmente } \\
\text { de terceiros }\end{array}$ \\
\hline MONOPLEGIA & $\begin{array}{l}\text { Não } \\
\text { recomendado }\end{array}$ & $\begin{array}{l}\text { Comprometiment } \\
\text { o da mobilidade e } \\
\text { da força }\end{array}$ & - & $\begin{array}{l}\text { Demanda } \\
\text { adaptação em } \\
\text { equipamentos } \\
\text {, geralmente } \\
\text { de terceiros }\end{array}$ \\
\hline MONOPARESIA & $\begin{array}{l}\text { Não } \\
\text { recomendado }\end{array}$ & $\begin{array}{ll}\text { Redução } & \text { da } \\
\text { mobilidade e da } \\
\text { força }\end{array}$ & - & $\begin{array}{l}\text { Demanda } \\
\text { adaptação em } \\
\text { equipamentos } \\
\text {, geralmente } \\
\text { de terceiros }\end{array}$ \\
\hline $\begin{array}{l}\text { PRÓTESE } \\
\text { UNILATERAL }\end{array}$ & Recomendado & & & \\
\hline
\end{tabular}

Disponível em: https://www.nucleodoconhecimento.com.br/engenharia-civil/portadores-de- 


\begin{tabular}{|c|c|c|c|c|}
\hline $\begin{array}{l}\text { ENCURTAMENT } \\
\text { O C/ BOTA }\end{array}$ & Recomendado & & & \\
\hline $\begin{array}{l}\text { PÉ } \quad \text { TORTO } \\
\text { CONGÊNITO }\end{array}$ & $\begin{array}{l}\text { Não } \\
\text { recomendado }\end{array}$ & $\begin{array}{l}\text { Redução da } \\
\text { mobilidade } \\
\text { dificuldade para } \\
\text { operar } \\
\text { equipamentos }\end{array}$ & - & $\begin{array}{l}\text { Demanda } \\
\text { adaptação em } \\
\text { equipamentos } \\
\text { geralmente } \\
\text { de terceiros }\end{array}$ \\
\hline $\begin{array}{l}\text { GENU VARU OU } \\
\text { VALGO }\end{array}$ & $\begin{array}{l}\text { Recomendado } \\
\text { parcialmente }\end{array}$ & $\begin{array}{ll}\text { Grau } & \text { de } \\
\text { deficiência } & \end{array}$ & - & - \\
\hline $\begin{array}{l}\text { DEFICIÊNCIA } \\
\text { AUDITIVA }\end{array}$ & $\begin{array}{l}\text { Não } \\
\text { recomendado }\end{array}$ & $\begin{array}{l}\text { Demanda } \\
\text { radiocomunicaçã } \\
\text { o }\end{array}$ & - & - \\
\hline $\begin{array}{l}\text { DEFICIÊNCIA } \\
\text { INTELECTUAL } \\
\text { MODERADA }\end{array}$ & $\begin{array}{l}\text { Não } \\
\text { recomendado }\end{array}$ & $\begin{array}{l}\text { Dificuldade para } \\
\text { entender e operar } \\
\text { equipamento }\end{array}$ & - & - \\
\hline
\end{tabular}

Fonte: Sinduscon/SP (2015)

Quadro 14 - Matriz de Viabilidade de Inserção - Operador de Guincho

\begin{tabular}{|c|c|c|c|c|}
\hline $\begin{array}{l}\text { Deficiência / } \\
\text { subtipos/Atividade } \\
\text { s }\end{array}$ & $\begin{array}{l}\text { Recomendaçã } \\
\text { o }\end{array}$ & Tipo de Restrição & $\begin{array}{l}\text { Local de } \\
\text { Restriçãa } \\
0\end{array}$ & Adaptações \\
\hline $\begin{array}{l}\text { Deficiência Física } \\
\text { Nanismo }\end{array}$ & $\begin{array}{l}\text { Não } \\
\text { recomendado }\end{array}$ & $\begin{array}{lr}\text { Força reduzida } \\
\text { devido } \\
\text { compleição física }\end{array}$ & & \\
\hline $\begin{array}{l}\text { Deficiência física } \\
\text { de membros } \\
\text { inferiores }\end{array}$ & & & & \\
\hline PARAPLEGIA & $\begin{array}{l}\text { Não } \\
\text { recomendado }\end{array}$ & $\begin{array}{l}\text { Comprometiment } \\
0 \text { total da }\end{array}$ & - & $\begin{array}{l}\text { Demanda } \\
\text { adaptação em }\end{array}$ \\
\hline
\end{tabular}




\begin{tabular}{|c|c|c|c|c|}
\hline & & $\begin{array}{l}\text { mobilidade e da } \\
\text { força }\end{array}$ & & $\begin{array}{l}\text { equipamentos } \\
, \text { geralmente } \\
\text { de terceiros }\end{array}$ \\
\hline MONOPLEGIA & $\begin{array}{l}\text { Não } \\
\text { recomendado }\end{array}$ & $\begin{array}{l}\text { Comprometiment } \\
\text { o da mobilidade e } \\
\text { da força }\end{array}$ & - & $\begin{array}{l}\text { Demanda } \\
\text { adaptação em } \\
\text { equipamentos } \\
\text {, geralmente } \\
\text { de terceiros }\end{array}$ \\
\hline MONOPARESIA & $\begin{array}{l}\text { Não } \\
\text { recomendado }\end{array}$ & $\begin{array}{l}\text { Redução da } \\
\text { mobilidade e da } \\
\text { força }\end{array}$ & - & $\begin{array}{l}\text { Demanda } \\
\text { adaptação em } \\
\text { equipamentos } \\
\text {, geralmente } \\
\text { de terceiros }\end{array}$ \\
\hline $\begin{array}{l}\text { PRÓTESE } \\
\text { UNILATERAL }\end{array}$ & Recomendado & & & \\
\hline $\begin{array}{l}\text { ENCURTAMENT } \\
\text { O C/ BOTA }\end{array}$ & Recomendado & & & \\
\hline $\begin{array}{l}\text { PÉ TORTO } \\
\text { CONGÊNITO }\end{array}$ & $\begin{array}{l}\text { Não } \\
\text { recomendado }\end{array}$ & $\begin{array}{l}\text { Redução da } \\
\text { mobilidade } \\
\text { dificuldade para } \\
\text { operar } \\
\text { equipamentos }\end{array}$ & - & $\begin{array}{l}\text { Demanda } \\
\text { adaptação em } \\
\text { equipamentos } \\
\text {, geralmente } \\
\text { de terceiros }\end{array}$ \\
\hline $\begin{array}{l}\text { GENU VARU OU } \\
\text { VALGO }\end{array}$ & $\begin{array}{l}\text { Recomendado } \\
\text { parcialmente }\end{array}$ & $\begin{array}{l}\text { Grau de } \\
\text { deficiência }\end{array}$ & - & - \\
\hline $\begin{array}{l}\text { DEFICIÊNCIA } \\
\text { AUDITIVA }\end{array}$ & Recomendado & & - & - \\
\hline $\begin{array}{l}\text { DEFICIÊNCIA } \\
\text { INTELECTUAL } \\
\text { MODERADA }\end{array}$ & $\begin{array}{l}\text { Não } \\
\text { recomendado }\end{array}$ & $\begin{array}{l}\text { Dificuldade para } \\
\text { entender e operar } \\
\text { equipamento }\end{array}$ & - & - \\
\hline
\end{tabular}

Fonte: Sinduscon/SP (2015)

Disponível em: https://www.nucleodoconhecimento.com.br/engenharia-civil/portadores-de- 
O quadro 15 ilustra a matriz de viabilidade de inserção do Operador de Guindaste.

Quadro 15 - Matriz de Viabilidade de Inserção - Operador de Guindaste

\begin{tabular}{|c|c|c|c|c|}
\hline $\begin{array}{l}\text { Deficiência / } \\
\text { subtipos/Atividade } \\
\text { s }\end{array}$ & $\begin{array}{l}\text { Recomendaçã } \\
\text { o }\end{array}$ & Tipo de Restrição & $\begin{array}{l}\text { Local de } \\
\text { Restriçã } \\
\text { o }\end{array}$ & Adaptações \\
\hline $\begin{array}{l}\text { Deficiência Física } \\
\text { Nanismo }\end{array}$ & $\begin{array}{l}\text { Não } \\
\text { recomendado }\end{array}$ & $\begin{array}{l}\text { Impossibilidade } \\
\text { de operação do } \\
\text { equipamento } \\
\text { devido à } \\
\text { compleição física }\end{array}$ & & $\begin{array}{l}\text { Demanda } \\
\text { adaptação em } \\
\text { equipamentos } \\
\text { geralmente } \\
\text { de terceiros }\end{array}$ \\
\hline \multicolumn{5}{|l|}{$\begin{array}{l}\text { Deficiência física } \\
\text { de membros } \\
\text { inferiores }\end{array}$} \\
\hline PARAPLEGIA & $\begin{array}{l}\text { Não } \\
\text { recomendado }\end{array}$ & $\begin{array}{l}\text { Comprometiment } \\
0 \quad \text { total da } \\
\text { mobilidade e da } \\
\text { força }\end{array}$ & - & $\begin{array}{l}\text { Demanda } \\
\text { adaptação em } \\
\text { equipamentos } \\
\text {, geralmente } \\
\text { de terceiros }\end{array}$ \\
\hline MONOPLEGIA & $\begin{array}{l}\text { Não } \\
\text { recomendado }\end{array}$ & $\begin{array}{l}\text { Comprometiment } \\
\text { o da mobilidade e } \\
\text { da força }\end{array}$ & - & $\begin{array}{l}\text { Demanda } \\
\text { adaptação em } \\
\text { equipamentos } \\
\text { geralmente } \\
\text { de terceiros }\end{array}$ \\
\hline MONOPARESIA & $\begin{array}{l}\text { Não } \\
\text { recomendado }\end{array}$ & $\begin{array}{ll}\text { Redução } & \text { da } \\
\text { mobilidade e da } \\
\text { força }\end{array}$ & - & $\begin{array}{l}\text { Demanda } \\
\text { adaptação em } \\
\text { equipamentos } \\
\text { geralmente } \\
\text { de terceiros }\end{array}$ \\
\hline
\end{tabular}

Disponível em: https://www.nucleodoconhecimento.com.br/engenharia-civil/portadores-de- 


\begin{tabular}{|c|c|c|c|c|}
\hline $\begin{array}{l}\text { PRÓTESE } \\
\text { UNILATERAL }\end{array}$ & Recomendado & & & \\
\hline $\begin{array}{l}\text { ENCURTAMENT } \\
\text { O C/ BOTA }\end{array}$ & Recomendado & & & \\
\hline $\begin{array}{l}\text { PÉ TORTO } \\
\text { CONGÊNITO }\end{array}$ & $\begin{array}{l}\text { Não } \\
\text { recomendado }\end{array}$ & $\begin{array}{l}\text { Redução da } \\
\text { mobilidade } \\
\text { dificuldade para } \\
\text { operar } \\
\text { equipamentos }\end{array}$ & 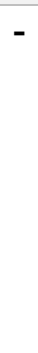 & $\begin{array}{l}\text { Demanda } \\
\text { adaptação em } \\
\text { equipamentos } \\
\text { geralmente } \\
\text { de terceiros }\end{array}$ \\
\hline $\begin{array}{l}\text { GENU VARU OU } \\
\text { VALGO }\end{array}$ & $\begin{array}{l}\text { Recomendado } \\
\text { parcialmente }\end{array}$ & $\begin{array}{l}\text { Grau de } \\
\text { deficiência }\end{array}$ & - & - \\
\hline $\begin{array}{l}\text { DEFICIÊNCIA } \\
\text { AUDITIVA }\end{array}$ & $\begin{array}{l}\text { Não } \\
\text { Recomendado }\end{array}$ & $\begin{array}{l}\text { Demanda } \\
\text { radiocomunicaçã } \\
\text { o }\end{array}$ & - & - \\
\hline $\begin{array}{l}\text { DEFICIÊNCIA } \\
\text { INTELECTUAL } \\
\text { MODERADA }\end{array}$ & $\begin{array}{l}\text { Não } \\
\text { recomendado }\end{array}$ & $\begin{array}{l}\text { Dificuldade para } \\
\text { entender e operar } \\
\text { equipamento }\end{array}$ & - & - \\
\hline
\end{tabular}

Fonte: Sinduscon/SP (2015)

O quadro 16 ilustra a matriz de viabilidade de inserção do Pedreiro.

Quadro 16 - Matriz de Viabilidade de Inserção - Pedreiro

\begin{tabular}{|l|l|l|l|l|}
\hline $\begin{array}{l}\text { Deficiência / } \\
\text { subtipos/Atividade } \\
\text { S }\end{array}$ & Recomendaçã & Tipo de Restrição & $\begin{array}{l}\text { Local de } \\
\text { Restriçã }\end{array}$ & Adaptações \\
\hline $\begin{array}{l}\text { Deficiência Física } \\
\text { Nanismo }\end{array}$ & $\begin{array}{l}\text { Recomendado } \\
\text { parcialmente }\end{array}$ & Esforço físico & & Ferramental \\
\hline $\begin{array}{l}\text { Deficiência física } \\
\text { de membros } \\
\text { inferiores }\end{array}$ & & & & \\
\hline
\end{tabular}

Disponível em: https://www.nucleodoconhecimento.com.br/engenharia-civil/portadores-de- 


\begin{tabular}{|c|c|c|c|c|}
\hline PARAPLEGIA & $\begin{array}{l}\text { Não } \\
\text { recomendado }\end{array}$ & $\begin{array}{l}\text { Comprometiment } \\
0 \quad \text { total da } \\
\text { mobilidade e da } \\
\text { força }\end{array}$ & - & - \\
\hline MONOPLEGIA & $\begin{array}{l}\text { Não } \\
\text { recomendado }\end{array}$ & $\begin{array}{l}\text { Comprometiment } \\
\text { o da mobilidade e } \\
\text { da força }\end{array}$ & - & - \\
\hline MONOPARESIA & $\begin{array}{l}\text { Recomendado } \\
\text { parcialmente }\end{array}$ & Esforço físico & $\begin{array}{l}\text { Externo } \\
\text { em } \\
\text { altura e } \\
\text { andaime }\end{array}$ & - \\
\hline $\begin{array}{l}\text { PRÓTESE } \\
\text { UNILATERAL }\end{array}$ & Recomendado & - & & \\
\hline $\begin{array}{l}\text { ENCURTAMENT } \\
\text { O C/ BOTA }\end{array}$ & Recomendado & - & & \\
\hline $\begin{array}{l}\text { PÉ TORTO } \\
\text { CONGÊNITO }\end{array}$ & $\begin{array}{l}\text { Recomendado } \\
\text { parcialmente }\end{array}$ & Esforço físico & $\begin{array}{l}\text { Externo } \\
\text { em } \\
\text { altura e } \\
\text { andaime }\end{array}$ & - \\
\hline $\begin{array}{l}\text { GENU VARU OU } \\
\text { VALGO }\end{array}$ & Recomendado & & - & - \\
\hline $\begin{array}{l}\text { DEFICIÊNCIA } \\
\text { AUDITIVA }\end{array}$ & $\begin{array}{l}\text { Recomendado } \\
\text { parcialmente }\end{array}$ & $\begin{array}{l}\text { Comunicação à } \\
\text { distância }\end{array}$ & $\begin{array}{l}\text { Fora do } \\
\text { alcance } \\
\text { visual }\end{array}$ & $\begin{array}{l}\text { - } \\
\text { Acessibilidade } \\
\text { comunicacion } \\
\text { al }\end{array}$ \\
\hline $\begin{array}{l}\text { DEFICIÊNCIA } \\
\text { INTELECTUAL } \\
\text { MODERADA }\end{array}$ & $\begin{array}{l}\text { Não } \\
\text { recomendado }\end{array}$ & $\begin{array}{l}\text { Envolve precisão } \\
\text { e dificuldade para } \\
\text { entender e operar } \\
\text { equipamento }\end{array}$ & - & - \\
\hline
\end{tabular}

Fonte: Sinduscon/SP (2015)

Disponível em: https://www.nucleodoconhecimento.com.br/engenharia-civil/portadores-de- 
O quadro 17 ilustra a matriz de viabilidade de inserção do Pedreiro de Fachada e o quadro 18 a do Pintor.

Quadro 17 - Matriz de Viabilidade de Inserção - Pedreiro de Fachada

\begin{tabular}{|c|c|c|c|c|}
\hline $\begin{array}{l}\text { Deficiência / } \\
\text { subtipos/Atividade } \\
\text { s }\end{array}$ & $\begin{array}{l}\text { Recomendaçã } \\
\text { o }\end{array}$ & Tipo de Restrição & $\begin{array}{l}\text { Local de } \\
\text { Restriçãa } \\
\text { o }\end{array}$ & $\begin{array}{l}\text { Adaptaçõe } \\
\text { s }\end{array}$ \\
\hline $\begin{array}{l}\text { Deficiência Física } \\
\text { Nanismo }\end{array}$ & $\begin{array}{l}\text { Recomendado } \\
\text { parcialmente }\end{array}$ & Esforço físico & - & - \\
\hline \multicolumn{5}{|l|}{$\begin{array}{l}\text { Deficiência física } \\
\text { de membros } \\
\text { inferiores }\end{array}$} \\
\hline PARAPLEGIA & $\begin{array}{l}\text { Não } \\
\text { recomendado }\end{array}$ & $\begin{array}{l}\text { Comprometiment } \\
0 \quad \text { total da } \\
\text { mobilidade e da } \\
\text { força }\end{array}$ & - & - \\
\hline MONOPLEGIA & $\begin{array}{l}\text { Não } \\
\text { recomendado }\end{array}$ & $\begin{array}{l}\text { Comprometiment } \\
\text { o da mobilidade e } \\
\text { da força }\end{array}$ & - & - \\
\hline MONOPARESIA & $\begin{array}{l}\text { Não } \\
\text { recomendado }\end{array}$ & $\begin{array}{l}\text { Diminuição } \quad \text { da } \\
\text { mobilidade e da } \\
\text { força }\end{array}$ & - & - \\
\hline $\begin{array}{l}\text { PRÓTESE } \\
\text { UNILATERAL }\end{array}$ & Recomendado & - & & \\
\hline $\begin{array}{l}\text { ENCURTAMENTO } \\
\text { C/ BOTA }\end{array}$ & Recomendado & - & & \\
\hline $\begin{array}{l}\text { PÉ TORTO } \\
\text { CONGÊNITO }\end{array}$ & $\begin{array}{l}\text { Não } \\
\text { Recomendado }\end{array}$ & $\begin{array}{l}\text { Diminuição } \text { da } \\
\text { mobilidade e da } \\
\text { força }\end{array}$ & & - \\
\hline
\end{tabular}

Disponível em: https://www.nucleodoconhecimento.com.br/engenharia-civil/portadores-de- 


\begin{tabular}{|l|l|l|l|}
\hline $\begin{array}{l}\text { GENU VARU OU } \\
\text { VALGO }\end{array}$ & Recomendado & & - \\
\hline $\begin{array}{l}\text { DEFICIÊNCIA } \\
\text { AUDITIVA }\end{array}$ & $\begin{array}{l}\text { Não } \\
\text { Recomendado }\end{array}$ & $\begin{array}{l}\text { Impossibilidade } \\
\text { de comunicação à } \\
\text { distância }\end{array}$ & \\
\hline $\begin{array}{l}\text { DEFICIÊNCIA } \\
\text { INTELECTUAL } \\
\text { MODERADA }\end{array}$ & $\begin{array}{l}\text { Não } \\
\text { recomenolve precisão }\end{array}$ & - & - \\
\hline
\end{tabular}

Fonte: Sinduscon/SP (2015)

Quadro 18 - Matriz de Viabilidade de Inserção - Pintor

\begin{tabular}{|c|c|c|c|c|}
\hline $\begin{array}{l}\text { Deficiência / } \\
\text { subtipos/Atividade } \\
\text { s }\end{array}$ & $\begin{array}{l}\text { Recomendaçã } \\
\text { o }\end{array}$ & Tipo de Restrição & $\begin{array}{l}\text { Local de } \\
\text { Restriçã } \\
0\end{array}$ & Adaptações \\
\hline $\begin{array}{l}\text { Deficiência Física } \\
\text { Nanismo }\end{array}$ & $\begin{array}{l}\text { Recomendado } \\
\text { parcialmente }\end{array}$ & Esforço físico & $\begin{array}{l}\text { Externo } \\
\text { em } \\
\text { altura e } \\
\text { cordeiro }\end{array}$ & Ferramental \\
\hline $\begin{array}{l}\text { Deficiência física } \\
\text { de membros } \\
\text { inferiores }\end{array}$ & & & & \\
\hline PARAPLEGIA & $\begin{array}{l}\text { Não } \\
\text { recomendado }\end{array}$ & $\begin{array}{l}\text { Comprometiment } \\
0 \quad \text { total da } \\
\text { mobilidade e da } \\
\text { força }\end{array}$ & - & - \\
\hline MONOPLEGIA & $\begin{array}{l}\text { Não } \\
\text { recomendado }\end{array}$ & $\begin{array}{l}\text { Comprometiment } \\
\text { o da mobilidade e } \\
\text { da força }\end{array}$ & - & - \\
\hline
\end{tabular}

Disponível em: https://www.nucleodoconhecimento.com.br/engenharia-civil/portadores-de- 


\begin{tabular}{|c|c|c|c|c|}
\hline MONOPARESIA & $\begin{array}{l}\text { Recomendado } \\
\text { parcialmente }\end{array}$ & $\begin{array}{l}\text { Esforço físico e } \\
\text { mobilidade } \\
\text { reduzida }\end{array}$ & $\begin{array}{l}\text { Externo } \\
\text { em } \\
\text { altura e } \\
\text { andaime }\end{array}$ & $\begin{array}{l}\text { Acessibilidade } \\
\text { específica }\end{array}$ \\
\hline $\begin{array}{l}\text { PRÓTESE } \\
\text { UNILATERAL }\end{array}$ & Recomendado & - & & \\
\hline $\begin{array}{l}\text { ENCURTAMENT } \\
\text { O C/ BOTA }\end{array}$ & Recomendado & - & & \\
\hline $\begin{array}{l}\text { PÉ TORTO } \\
\text { CONGÊNITO }\end{array}$ & Recomendado & & & - \\
\hline $\begin{array}{l}\text { GENU VARU OU } \\
\text { VALGO }\end{array}$ & Recomendado & & - & - \\
\hline $\begin{array}{l}\text { DEFICIÊNCIA } \\
\text { AUDITIVA }\end{array}$ & $\begin{array}{l}\text { Recomendado } \\
\text { parcialmente }\end{array}$ & $\begin{array}{l}\text { Comunicação à } \\
\text { distância }\end{array}$ & $\begin{array}{l}\text { Fora do } \\
\text { alcance } \\
\text { visual }\end{array}$ & $\begin{array}{l}\text { - } \\
\text { Acessibilidade } \\
\text { comunicacion } \\
\text { al }\end{array}$ \\
\hline $\begin{array}{l}\text { DEFICIÊNCIA } \\
\text { INTELECTUAL } \\
\text { MODERADA }\end{array}$ & $\begin{array}{l}\text { Não } \\
\text { recomendado }\end{array}$ & Envolve precisão & - & - \\
\hline
\end{tabular}

Fonte: Sinduscon/SP (2015)

O quadro 19 ilustra a matriz de viabilidade de inserção do Poceiro e o quadro 18 a do Serralheiro.

Quadro 19 - Matriz de Viabilidade de Inserção - Poceiro

\begin{tabular}{|l|l|l|l|l|}
\hline $\begin{array}{l}\text { Deficiência } \\
\text { subtipos/Atividade } \\
\text { S }\end{array}$ & Recomendaçã & Tipo de Restrição & $\begin{array}{l}\text { Local de } \\
\text { Restriçã }\end{array}$ & Adaptaçõe \\
\hline $\begin{array}{l}\text { Deficiência Física } \\
\text { Nanismo }\end{array}$ & Não & Redução de força & - & \\
\hline
\end{tabular}

Disponível em: https://www.nucleodoconhecimento.com.br/engenharia-civil/portadores-de- 


\begin{tabular}{|c|c|c|c|c|}
\hline & & $\begin{array}{l}\text { devido a } \\
\text { compleição física }\end{array}$ & & \\
\hline \multicolumn{5}{|l|}{$\begin{array}{l}\text { Deficiência física } \\
\text { de membros } \\
\text { inferiores }\end{array}$} \\
\hline PARAPLEGIA & $\begin{array}{l}\text { Não } \\
\text { recomendado }\end{array}$ & $\begin{array}{l}\text { Comprometiment } \\
0 \quad \text { total da } \\
\text { mobilidade e da } \\
\text { força }\end{array}$ & - & - \\
\hline MONOPLEGIA & $\begin{array}{l}\text { Não } \\
\text { recomendado }\end{array}$ & $\begin{array}{l}\text { Comprometiment } \\
\text { o da mobilidade e } \\
\text { da força }\end{array}$ & - & - \\
\hline MONOPARESIA & $\begin{array}{l}\text { Não } \\
\text { recomendado }\end{array}$ & $\begin{array}{l}\text { Diminuição } \quad \text { da } \\
\text { mobilidade e da } \\
\text { força }\end{array}$ & - & - \\
\hline $\begin{array}{l}\text { PRÓTESE } \\
\text { UNILATERAL }\end{array}$ & Recomendado & - & & \\
\hline $\begin{array}{l}\text { ENCURTAMENTO } \\
\text { C/ BOTA }\end{array}$ & Recomendado & - & & \\
\hline $\begin{array}{l}\text { PÉ TORTO } \\
\text { CONGÊNITO }\end{array}$ & $\begin{array}{l}\text { Não } \\
\text { Recomendado }\end{array}$ & $\begin{array}{ll}\text { Diminuição } & \text { da } \\
\text { mobilidade e da } \\
\text { força }\end{array}$ & & - \\
\hline $\begin{array}{l}\text { GENU VARU OU } \\
\text { VALGO }\end{array}$ & Recomendado & & - & - \\
\hline $\begin{array}{l}\text { DEFICIÊNCIA } \\
\text { AUDITIVA }\end{array}$ & $\begin{array}{l}\text { Não } \\
\text { Recomendado }\end{array}$ & $\begin{array}{l}\text { Impossibilidade } \\
\text { de comunicação à } \\
\text { distância }\end{array}$ & & \\
\hline $\begin{array}{l}\text { DEFICIÊNCIA } \\
\text { INTELECTUAL } \\
\text { MODERADA }\end{array}$ & $\begin{array}{l}\text { Não } \\
\text { recomendado }\end{array}$ & $\begin{array}{l}\text { Envolve precisão } \\
\text { e dificuldade para }\end{array}$ & - & - \\
\hline
\end{tabular}

Disponível em: https://www.nucleodoconhecimento.com.br/engenharia-civil/portadores-de- 
Fonte: Sinduscon/SP (2015)

Quadro 20 - Matriz de Viabilidade de Inserção - Serralheiro

\begin{tabular}{|c|c|c|c|c|}
\hline $\begin{array}{l}\text { Deficiência } \\
\text { subtipos/Atividade } \\
\text { s }\end{array}$ & $\begin{array}{l}\text { Recomendaçã } \\
\text { O }\end{array}$ & Tipo de Restrição & $\begin{array}{l}\text { Local de } \\
\text { Restriçãa } \\
0\end{array}$ & Adaptações \\
\hline $\begin{array}{l}\text { Deficiência Física } \\
\text { Nanismo }\end{array}$ & $\begin{array}{l}\text { Recomendado } \\
\text { parcialmente }\end{array}$ & $\begin{array}{l}\text { Esforço físico e } \\
\text { empunhadura }\end{array}$ & - & Ferramental \\
\hline $\begin{array}{l}\text { Deficiência física } \\
\text { de membros } \\
\text { inferiores }\end{array}$ & & & & \\
\hline PARAPLEGIA & $\begin{array}{l}\text { Não } \\
\text { recomendado }\end{array}$ & $\begin{array}{l}\text { Comprometiment } \\
0 \quad \text { total da } \\
\text { mobilidade e da } \\
\text { força }\end{array}$ & - & - \\
\hline MONOPLEGIA & $\begin{array}{l}\text { Não } \\
\text { recomendado }\end{array}$ & $\begin{array}{l}\text { Comprometiment } \\
\text { o da mobilidade e } \\
\text { da força }\end{array}$ & - & - \\
\hline MONOPARESIA & $\begin{array}{l}\text { Recomendado } \\
\text { parcialmente }\end{array}$ & Esforço físico & - & - \\
\hline $\begin{array}{l}\text { PRÓTESE } \\
\text { UNILATERAL }\end{array}$ & Recomendado & & & \\
\hline $\begin{array}{l}\text { ENCURTAMENT } \\
\text { O C/ BOTA }\end{array}$ & Recomendado & & & \\
\hline $\begin{array}{l}\text { PÉ TORTO } \\
\text { CONGÊNITO }\end{array}$ & Recomendado & & & \\
\hline
\end{tabular}




\begin{tabular}{|l|l|l|l|l|}
\hline $\begin{array}{l}\text { GENU VARU OU } \\
\text { VALGO }\end{array}$ & Recomendado & & \\
\hline $\begin{array}{l}\text { DEFICIÉNCIA } \\
\text { AUDITIVA }\end{array}$ & $\begin{array}{l}\text { Recomendado } \\
\text { parcialmente }\end{array}$ & $\begin{array}{l}\text { Comunicação à } \\
\text { distância }\end{array}$ & $\begin{array}{l}\text { Externo } \\
\text { em } \\
\text { altura }\end{array}$ & $\begin{array}{l}\text { Acessibilidade } \\
\text { comunicacion } \\
\text { al }\end{array}$ \\
\hline $\begin{array}{l}\text { DEFICIÊNCIA } \\
\text { INTELECTUAL } \\
\text { MODERADA }\end{array}$ & $\begin{array}{l}\text { Não } \\
\text { recomendado }\end{array}$ & $\begin{array}{l}\text { Envolve precisão } \\
\text { e dificuldade para } \\
\text { entender operar } \\
\text { equipamento }\end{array}$ & & \\
& & & & \\
\end{tabular}

Fonte: Sinduscon/SP (2015)

O estudo da Sinduscon/SP (2015) deixou claro que é preciso analisar com critério a inclusão de Pessoas com Necessidades Especiais na Construção Civil, devido a especificidade das funções.

\section{CONSIDERAÇÕES FINAIS}

Conclui-se que a inserção de Pessoas com Necessidades Especiais no mercado de trabalho formal tem esbarrado em várias dificuldades e, especificamente no âmbito da Construção Civil, a questão é mais relevante, devido às questões da viabilidade de sua inserção nas diversas funções que o setor necessita. O setor da construção civil possui um alto índice de acidentes de trabalho e é necessária uma adequação às normas das áreas de vivência nos canteiros de obras, uma vez que é preciso que haja uma preocupação com a saúde e a segurança dos trabalhadores. As áreas de vivência propiciam momentos de relaxamento e sociabilidade no ambiente de trabalho, minimizando o estresse ocupacional e, com isso, diminuindo a incidência de absenteísmo.

Além disso, o estresse ocupacional dos funcionários de canteiros de obras ocorre devido à preocupação com a incidência de acidentes de trabalho. Os acidentes além de prejuízos ao trabalhador também ocasionam custos diretos e indiretos aos 
empresários, o que pode ser minimizado se estes tomarem atitudes coerentes nesse sentido. Muitos desses acidentes estão ligados à falta de treinamento $e$ conscientização por parte tanto dos gestores como dos empregados, que são negligentes em alguns aspectos. No tocante às áreas de vivência, objeto desse estudo, verifica-se que as empresas não atendem de forma total as exigências da NR18, propiciando, dessa forma, a ocorrência de acidentes e problemas com a saúde do trabalhador. Quanto à inserção de Pessoas com necessidades Especiais no mercado de trabalho da construção civil, observou-se que é possível, mas há a necessidade de subsídios técnicos para a inserção destes.

É necessário seguir as matrizes de viabilidade, levando em consideração o tipo de deficiência e a função a ser designada. Ainda são muitos os desafios a serem enfrentados nesse sentido, mas as perspectivas são boas, pois os empresários estão mais conscientes e os setores ligados ao segmento de construção civil têm se empenhado para aumentar a acessibilidade de Pessoas Portadoras de Necessidades no mercado de trabalho, com vistas a garantir a segurança de ambas as partes.

\section{REFERÊNCIAS}

ABREU, C. B. Curatela e interdição civil. Rio de Janeiro: Lumen Júris, 2009.

ARAÚJO, L. A. D. A proteção constitucional das pessoas portadoras de deficiência. 3aㅡ ed. Brasília: CORDE, 2001.

BRASIL. Constituição Federal. Constituição da República Federativa do Brasil. Brasília: Senado, 1988.

CAMPOS, J.; VASCONCELLOS, E., Kruglianskas, G. Incluindo pessoas com deficiência na empresa: estudo de caso de uma multinacional brasileira. Revista de Administração, v. 48, n. 3, p. 560-573, 2013.

CASTRO, A. P. de.; LAZZARI, J. B. Manual de direito previdenciário. 11ª ed. São Paulo: Conceito Editorial, 2009. 
GIL, M. O que as empresas podem fazer pela inclusão das pessoas com deficiências. São Paulo: Instituto Ethos, 2002.

IBGE - Instituto Brasileiro de Geografia e Estatística. Panorama Nacional e Internacional da Produção de Indicadores Sociais. 2018. Grupos Populacionais Específicos e uso do tempo. Disponível em: http://biblioteca.ibge.gov.br/index.pHp/bibliotecacatalogo?view=detalhes\&id=2101562. Acesso em: 06 ago. 2020.

IGLESIAS, V.; CARVALHO-FREITAS, M.; SUZANO, J. Estereótipos e preconceito em relação às pessoas com deficiência: a perspectiva dos gestores. In: Encontro Da Associação Nacional De Pós-Graduação E Pesquisa Em Administração, 37. Anais... Rio de Janeiro: Anpad, 2013.

LORENTZ, L.N. A norma da igualdade e o trabalho das pessoas portadoras de deficiência. São Paulo: LTr, 2006.

MACCALI, N. et al. As práticas de recursos humanos para a gestão da diversidade: a inclusão de deficientes intelectuais em uma federação pública do brasil. Revista de Administração Mackenzie, v.16, n. 2, p. 157-187, 2015.

NEPOMUCENO, M. F; CARVALHO-FREITAS, M. N. As crenças e percepções dos gerentes e as possibilidades de trabalho das pessoas com deficiência. Psicologia em Pesquisa, v. 2, n. 1, pp. 81-94, 2008.

ROCHA, P. C.; LIMA, I. B. Inclusão de deficientes físicos no mercado de trabalho: estudo de caso em uma organização no segmento industrial. Revista Eletrônica Interdisciplinar em Negócios e Hospitalidade - REINH, v. 2, n. 1, pp. 74-93, 2014.

SAMPAIO, J. C. de. A. PCMAT: Programa de Condições e Meio Ambiente do Trabalho na Indústria da Construção. São Paulo: Pini; SINDUSCON/SP, 1998.

SASSAKI, R.K. Educação. In: RESENDE, A. P. C. de.; VITAL, F. M. de. P. (Coord.). Convenção sobre os direitos das pessoas com deficiência comentada. Brasília: 
Secretaria Especial dos Direitos Humanos. Coordenadoria Nacional para Integração da Pessoa Portadora de Deficiência - CORDE, pp.84-85.

Enviado: Maio, 2020.

Aprovado: Agosto, 2020. 